COMPARISON OF CONCEPTUALLY BASED AND REGRESSION RAINFALL-

RUNOFF MODELS, DENVER METROPOLITAN AREA, COLORADO,

AND POTENTIAL APPLICATIONS IN URBAN AREAS

By Juli B. Lindner-Lunsford and Sherman R. Ellis

U.S. GEOLOGICAL SURVEY

Water-Resources Investigations Report 87-4104

Denver, Colorado

1987

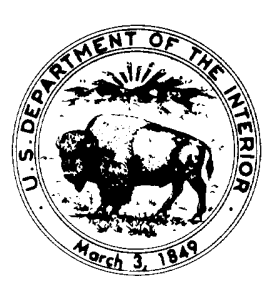


DEPARTMENT OF THE INTERIOR

DONALD PAUL HODEL, Secretary

U.S. GEOLOGICAL SURVEY

Dallas L. Peck, Director

For additional information write to:

District Chief U.S. Geological Survey Water Resources Division Box 25046, Mail Stop 415

Federal Center

Denver, CO 80225
Copies of this report can be purchased from:

U.S. Geological Survey Books and Open-File Reports Federal Center, Bldg. 810 Box 25425

Denver, CO 80225 
Abstract--

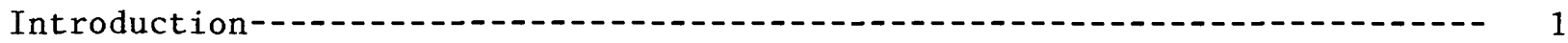

Basin descriptions-0.

Method of study------

Model descriptions and comparisons--

Data requirements-----

Implementation time--0.- 9

Detail of results----

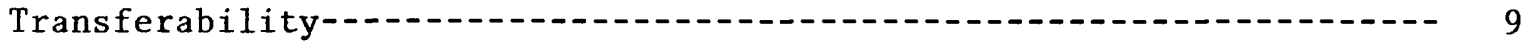

Comparison of model results--

North Avenue basin----

Northglenn basin------

Cherry Knolls basin--

Villa Italia basin----

Potential applications in urban areas--

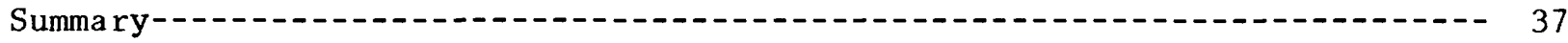

References cited----

\section{FIGURES}

Figure 1. Map showing location of study area, monitoring sites, and general features-----

2-8. Graphs showing:

2. Simulated and measured storm-runoff volumes and peak flows for the verification data set for the North Avenue basin----

3. Simulated and measured storm-runoff loads for selected constituents for the verification data set for the North Avenue basin---18

4. Simulated and measured storm-runoff volumes and peak flows for the verification data set for the Northglenn basin------ 21

5. Simulated and measured storm-runoff volumes and peak flows for the verification data set for the Cherry Knolls basin--- 21

6. Simulated and measured storm-runoff loads for selected constituents for the verification data set for the Cherry Knolls basin-- 26

7. Simulated and measured storm-runoff volumes and peak flows for the verification data set for the Villa Italia basin---- 34

8. Simulated and measured storm-runoff loads for selected constituents for the verification data set for the Villa

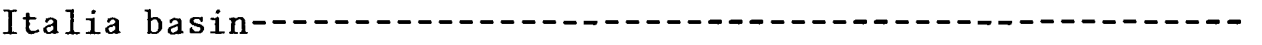

\section{TABLES}

2. Coefficients and form of regression equations--- 7

3 . Comparison of conceptually based and regression flow-model calibration results for the North Avenue basin---- 11

4. Comparison of conceptually based and regression flow-model verification results for the North Avenue basin---.- 
Table 5. Comparison of conceptually based and regression quality-model calibration results for the. North Avenue basin---- 14

6. Comparison of conceptually based and regression quality-model verification results for the North Avenue basin--.-.-.- 16

7. Comparison of conceptually based and regression flow-model calibration results for the Northglenn basin---19

8. Comparison of conceptually based and regression flow-model verification results for the Northglenn basin---- 20

9. Comparison of conceptually based and regression flow-model calibration results for the Cherry Knolls basin--.-.- 22

10. Comparison of conceptually based and regression flow-model verification results for the Cherry Knolls basin---.-- 23

11. Comparison of conceptually based and regression quality-model calibration results for the Cherry Knolls basin---- 24

12. Comparison of conceptually based and regression flow-model calibration results for the Villa Italia basin---.-.-.-- 28

13. Comparison of conceptually based and regression flow-model verification results for the Villa Italia basin---.------ 29

14. Comparison of conceptually based and regression quality-model calibration results for the Villa Italia basin------.---- 30

15. Comparison of conceptually based and regression quality-model verification results for the Villa Italia basin--.-.----- 32

\section{CONVERSION FACTORS}

Factors for converting inch-pound units used in this report to metric (International System) units are shown in the following table:

Multiply inch-pound unit

acre

cubic foot per second

inch

pound
$B y$

To obtain metric unit

hectare

cubic meter per second

centimeter

kilogram 


\title{
COMPARISON OF CONCEPTUALLY BASED AND REGRESSION RAINFALL-RUNOFF \\ MODELS, DENVER METROPOLITAN AREA, COLORADO, AND POTENTIAL APPLICATIONS IN URBAN AREAS
}

By Juli B. Lindner-Lunsford and Sherman R. Ellis

\begin{abstract}
Multievent, conceptually based models and a single-event, multiple linear-regression model for estimating storm-runoff quantity and quality from urban areas were calibrated and verified for four small (57 to 167 acres) basins in the Denver metropolitan area, Colorado. The basins represented different land-use types--light commercial, single-family housing, and multifamily housing. Both types of models were calibrated using the same data set for each basin. A comparison was made between the storm-runoff volume, peak flow, and storm-runoff loads of seven water-quality constituents simulated by each of the models using identical verification data sets.
\end{abstract}

The multievent, conceptually based models studied were the U.S. Geological Survey's Distributed Routing Rainfall-Runoff Model--Version II (DR ${ }_{3} \mathrm{M}-\mathrm{II}$ ) (a runoff-quantity model designed for urban areas), and a multievent, urban runoff-quality model, $\mathrm{DR}_{3} \mathrm{M}$-QUAL. Water-quality constituents modeled were chemical oxygen demand, total suspended solids, total nitrogen, total phosphorus, total lead, total manganese, and total zinc.

A multiple linear-regression analysis, based both on log-transformed and untransformed data, was made. A separate regression equation was developed for each runoff characteristic or water-quality constituent, and all the regression equations were basin specific.

The two types of models produced comparable results for most runoff characteristics and water-quality constituents in the basins studied. However, development and implementation of multievent, conceptually based models are more costly and time consuming than development and implementation of single-event, multiple linear-regression models.

\section{INTRODUCTION}

Runoff from urban areas in the Denver metropolitan area (fig. 1) has been studied since the late $1960^{\prime} \mathrm{s}$ by Federal, State, and local agencies as well as by private consultants. Mathematical models of the processes of runoff from urban areas have been included in these studies since about 1975 (Ellis and Mustard, 1984). These studies have used a variety of models of varying degrees of complexity; the time frames have been both continuous or multievent and single event, and the model basis has been both empirical and conceptual. This report compares results from multievent, conceptually based models and single-event, multiple linear-regression models. For both models, measured 


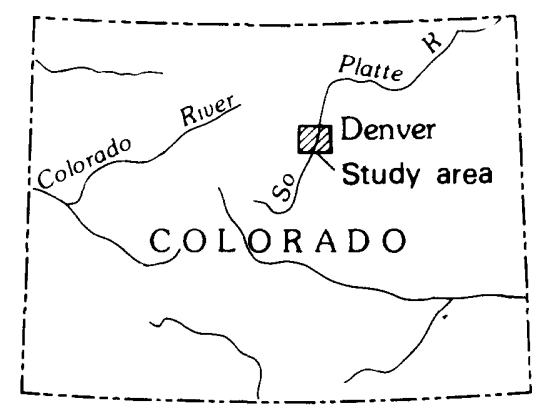

\section{EXPLANATION}

- 06720420

Northglenn

U. S. GEOLOGICAL SURVEY MONITORING SITE, NUMBER, AND BASIN NAME
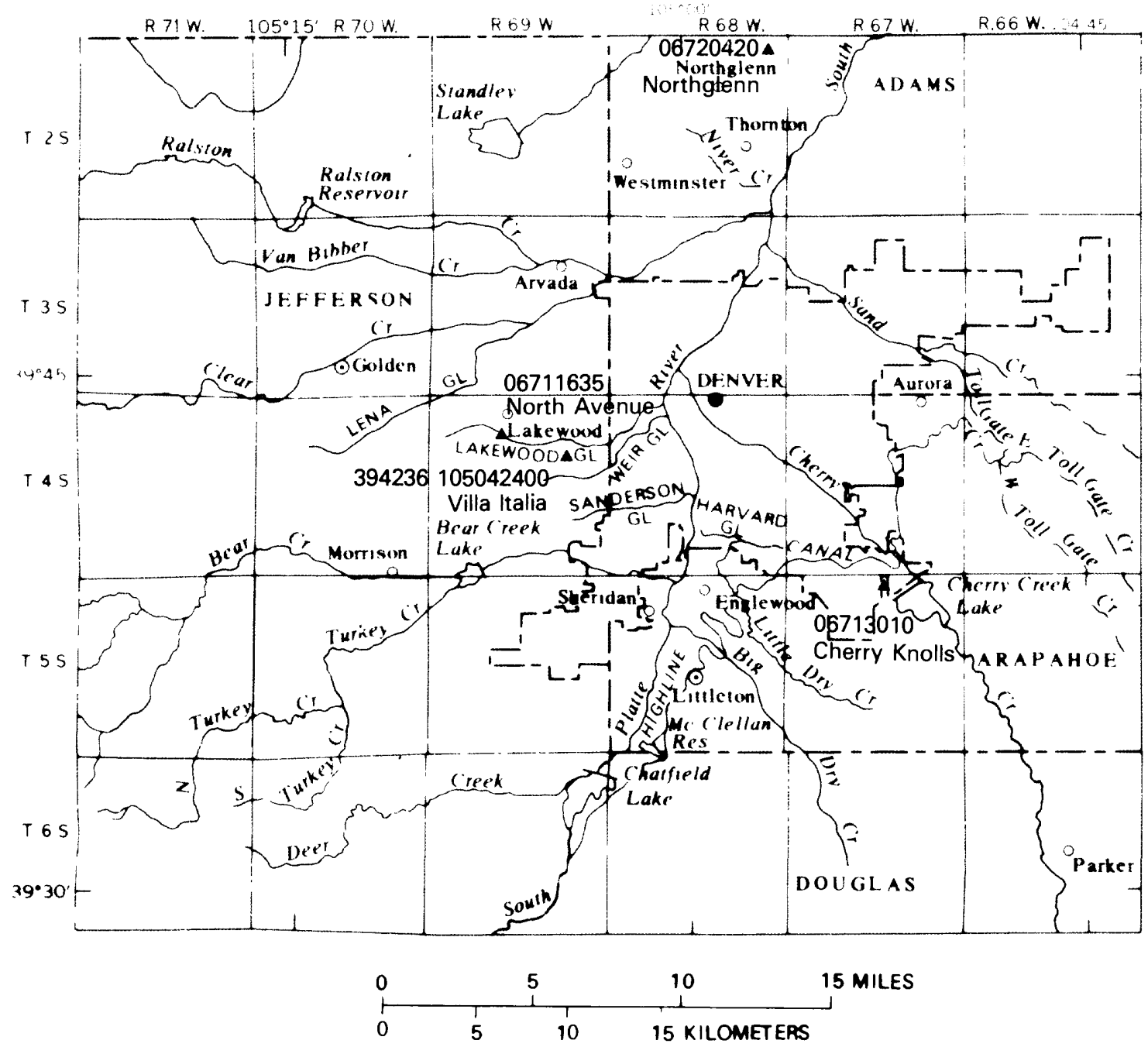

Figure 1.--Location of study area, monitoring sites, and general features. 
data from a verification data set is used as a standard of model performance. Storm characteristics modeled include: measured storm-runoff volumes, peak flows, and water-quality constituent loads (referred to hereafter as stormrunoff loads). Data from four basins of different land-use classifications are used in the analysis.

\section{BASIN DESCRIPTIONS}

The North Avenue basin consists of 69 acres in southwestern Lakewood, Colo., a western suburb of Denver (fig. 1). At the time of the datacollection phase of this study (1980-81), about 33 percent of the basin was devoted to multifamily housing, 30 percent to restaurants and office buildings, and 37 percent to undeveloped land. Fifty percent of the basin was identified as effective impervious area (table 1).

The Northglenn basin in a northern suburb of Denver (fig. 1), was the largest of the basins modeled ( 167 acres). The major land use in the basin during 1980-81 was single-family housing. This basin had the smallest percentage of effective impervious area of the four basins, about 24 percent (table 1).

The Cherry Knolls basin consists of 57 acres in southeast metropolitan Denver (fig. 1). The land use during 1980-81 was multifamily housing, although there were several open areas in the basin. The monitoring site was located at the outlet of a small detention basin, which had no effect on the outflow for the storms monitored. Thirty-eight percent of the basin was effective impervious area (table 1).

The 74-acre Villa Italia basin (fig. 1) consists of a large shopping mall in eastern Lakewood, the Villa Italia Shopping Center. An unusually large proportion of the basin, about 91 percent, was effective impervious area-mostly parking lots (table 1).

\section{METHOD OF STUDY}

Multievent, conceptually based rainfall-runoff models previously were calibrated and verified for five urban basins, and runoff-quality models were calibrated and verified for four of the basins as part of a cooperative project by the U.S. Geological Survey, the Denver Regional Council of Governments, and the U.S. Environmental Protection Agency (Lindner-Lunsford and E11is, 1984). The basins modeled were described in the previous section. Storm-runoff loads included in this study were chemical oxygen demand, total suspended solids, total nitrogen, total phosphorus, total lead, total manganese, and total zinc. (Throughout the report, the term total, as in "total lead," actually refers to "total recoverable" for trace elements.) Detailed discussions of calibration and verification procedures for these models and final values of model parameters were published by Lindner-Lunsford and E1lis (1984). Multiple linear-regression equations for storm-runoff volume and peak flow were developed for four of the basins studied by these authors as part of the present study; equations to simulate storm-runoff loads were developed for 


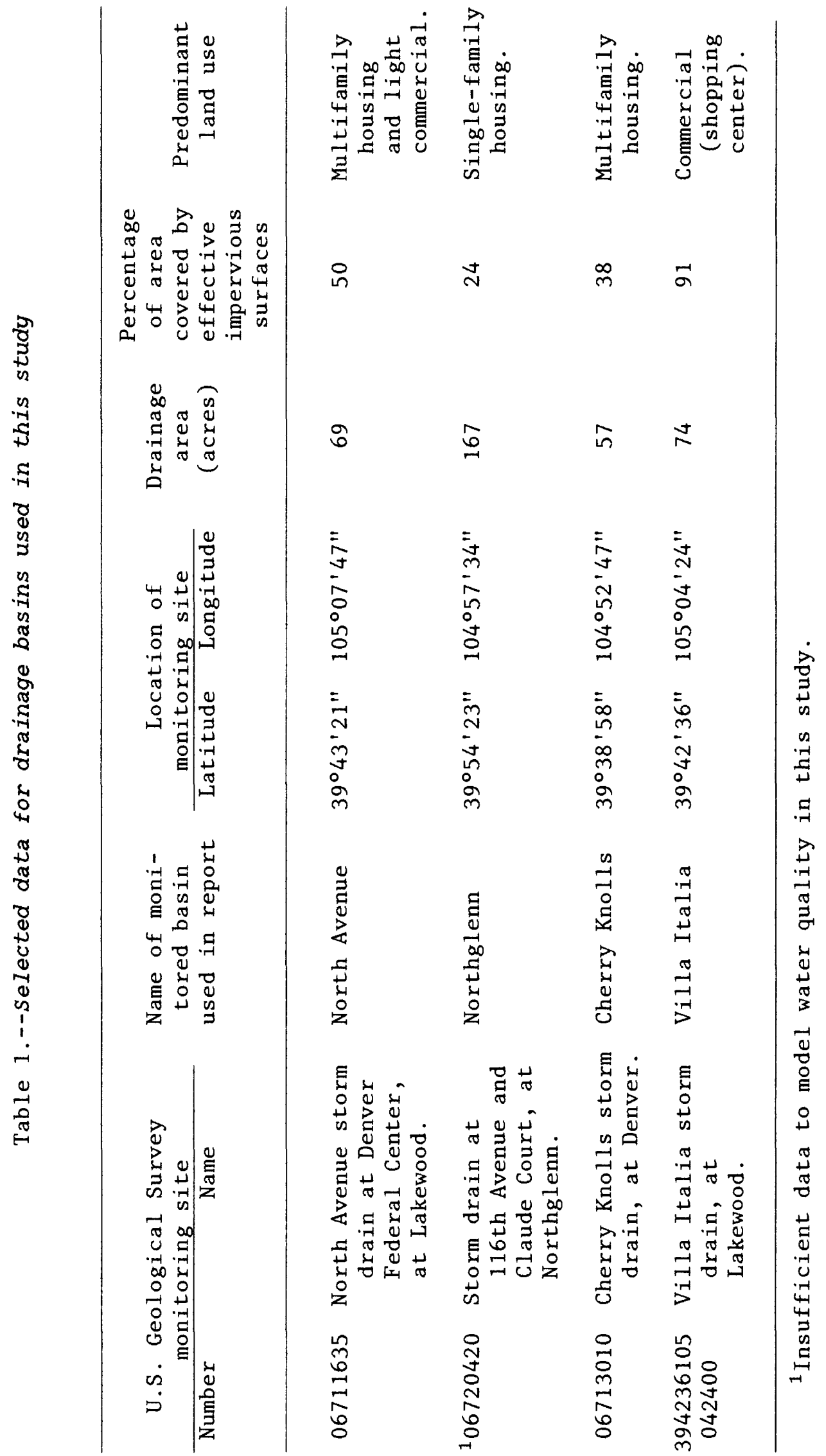


three of the basins. The Southglenn basin was completely eliminated from the present study, and the Northglenn basin was eliminated from the water-quality part of the present study, because there were insufficient data to establish meaningful regression equations.

Multiple linear-regression equations were developed for each of the basins. Separate regression equations were developed for storm-runoff volume, peak flow, and each of the water-quality-constituent storm-runoff loads. Only storms that had been used in the calibration of the conceptually based models were used to establish the regression coefficients, so that both models were calibrated using identical data sets. Calibration statistics are presented in this report to enable the reader to compare how accurately each of the models was able to match the given data. The conceptually based models and the regression models were verified using the same data sets, and only the statistics based on the verification data set were actually used to determine which of the models gave a better fit.

\section{MODEL DESCRIPTIONS AND COMPARISONS}

The U.S. Geological Survey's Distributed Routing Rainfal1-Runoff Mode1-Version II ( $\mathrm{DR}_{3} \mathrm{M}-\mathrm{II}$ ) (Alley and Smith, 1982a) is designed to simulate the quantity of storm runoff from urban areas. The model is based on a conceptualization of processes that occur in urban basins. The model provides detailed hydrographs at the outlet of the basin for selected storm-runoff periods and performs daily soil-moisture accounting for the periods between storms where detailed simulation is desired. Thus, the model is a multievent simulation model, rather than a single-event model.

The U.S. Geological Survey's DR 3 M-QUAL, a multievent, runoff-quality model (Alley and Smith, 1982b), is designed to simulate impervious area, pervious area, and precipitation contributions to quality of surface runoff in urban areas. Within-storm variations in runoff quality are simulated for selected storms; between these storms, a daily accounting of water-qualityconstituent accumulation and washoff is maintained. Spatial variations in water-quality-constituent accumulation and washoff parameters can be considered in the simulation. However, these were not used in this study. The lumped-parameter mode that was used instead was more compatible with the limitations of the regression models and the present degree of understanding of some of the basin processes.

By contrast, the single-event, multiple-linear-regression modeling approach is empirical. Two sets of multiple linear-regression equations were developed using the SAS Institute's Statistical Analysis System ${ }^{1}$. The procedure used was the 'MAXR' option of the 'STEPWISE' procedure. Detailed discussion of these procedures can be found in Helwig and Council (1979, p. 391-392). These single-event, multiple-linear-regression models are

\footnotetext{
${ }^{1}$ The use of trade names in this report is for identification only and does not constitute endorsement by the U.S. Geological Survey.
} 
referred to as REG (for storm-runoff volume and peak flow) and REG-QUAL (for storm-runoff loads) in the tables showing comparisons of the predictions of the two types of models, and as "the regression models" throughout the rest of this report.

For each of the basins, one regression equation was developed for untransformed data and one for $\log _{10}$-transformed data. The dependent variables modeled were storm-runoff volume, peak flow, and storm-runoff load of each of seven water-quality constituents. Independent variables considered are listed in the next section, "Data Requirements." However, not all of the variables were used in the final models. Independent variables had to be significant at a 95-percent level of confidence as measured by an F-test in order to be included in the equations. Standard errors and plots of residuals were examined to select the appropriate model, and the equation with the best fit for each constituent, either untransformed or $\log _{10}$-transformed, was used for further study.

$\log _{10}$-transformed regression equations are negatively biased (Miller, 1984; B.M. Troutman, U. S. Geological Survey, written commun., 1985) and need to be corrected using a bias correction factor ( $F$ in table 2 ). If the $\log _{10^{-}}$ transformed form of the regression equation was used " $L$ " in form of equation, table 2), transformation bias was corrected using the method of Miller (1984):

$$
\mathrm{Y}=\mathrm{aX} \mathrm{b}^{\mathrm{b}}
$$

where: $Y=$ the dependent variable of interest,

$\mathrm{X}=$ some independent variable,

$a$ and $b=$ regression coefficients, and

$\mathrm{F}=$ the bias correction factor.

The bias correction factor is calculated by:

$$
F=e^{0.5\left(S E^{2}\right)} \text {, }
$$

where e = base of natural logarithm, 2.178, and

$\mathrm{SE}=$ standard error of regression of natural log-transformed values.

For $\log _{10}$ logarithms, the bias correction factor is calculated by:

$$
\mathrm{F}=10^{2.303 \cdot 0.5\left(\mathrm{SE}^{2}\right),}
$$

where $\mathrm{SE}=$ standard error of regression of $\log _{10} \log$-transformed values

The bias correction factor for untransformed standard error of estimation, using Hardison's (1971) coversion of natural logarithms to standard error of estimation is calculated by:

$$
F=e^{0.5(\operatorname{Ln}(\mathrm{SEE})+1)^{2}}
$$

where $\mathrm{Ln}=$ natural logarithm, and

SEE = standard error of estimation, untransformed, in percent, divided by 100 . 
[Form of equation: $U$ : load, in pounds = (Axantecedent dry days, in days) + (Bxtotal rainfall, in hundredths of an inch) + (CXduration of storm, in minutes) + (DXmaximum rainfall intensity, in hundredths of an inch during 5 minutes) $+\mathrm{E} ; \mathrm{L}$ : load, in pounds $=10^{\mathrm{E}} \times$ (antecedent dry days, in days) ${ }^{\mathrm{A}} \times$ (total rainfall, in hundredths of an inch) $B_{x}$ (duration of storm, in minutes) ${ }^{C} \times$ (maximum rainfall intensity, in hundredths of an inch during 5 minutes) ${ }^{D} F$. Dashes indicate an independent variable not significant at 95 -percent confidence level and not used in equations. $\mathrm{NA}=$ not applicable]

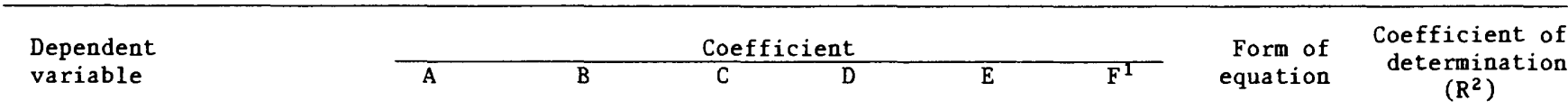

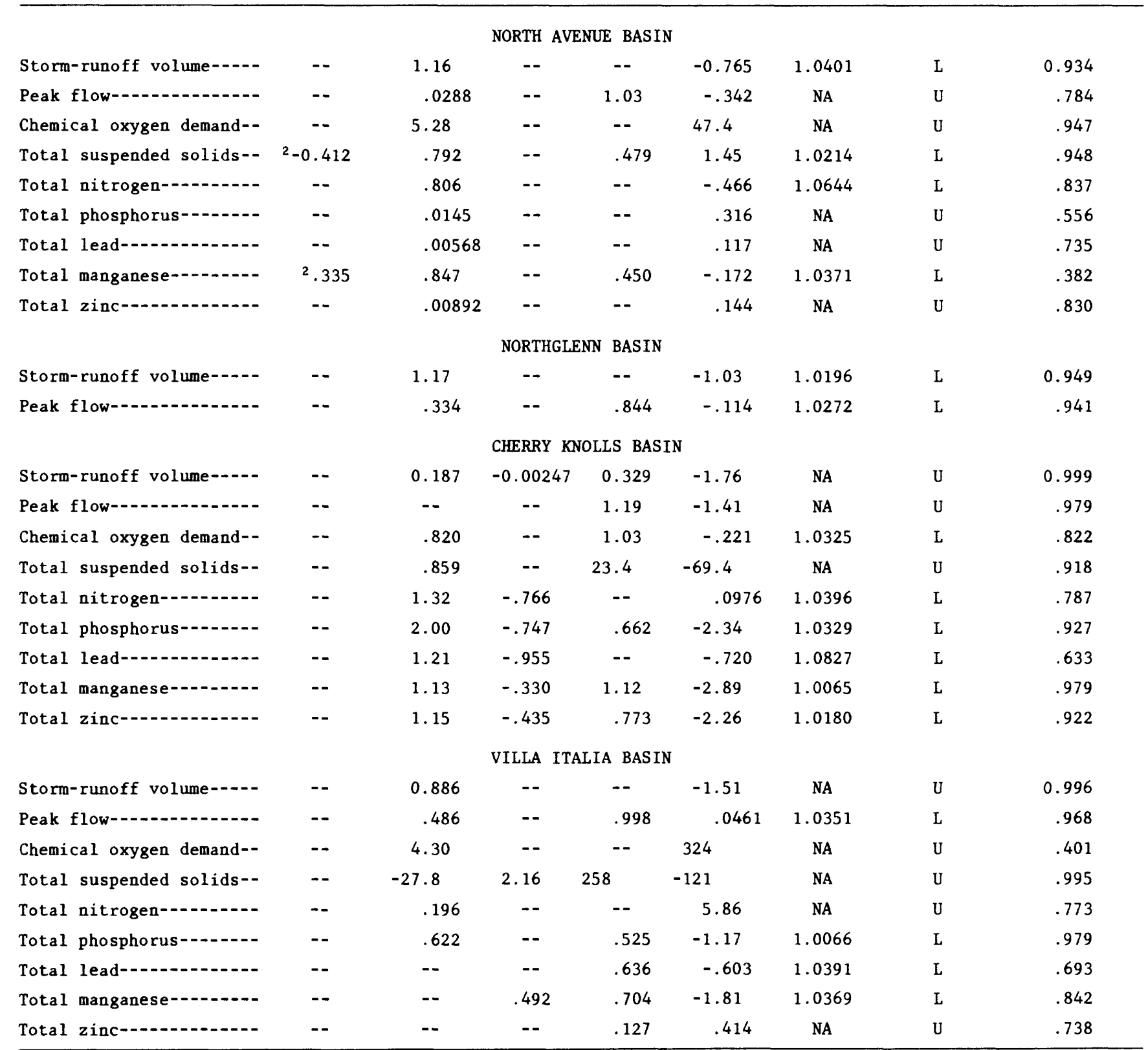

${ }^{1} \mathrm{~F}$ is a correction factor for transformation bias.

${ }^{2} \mathrm{~A}$ value for antecedent dry days of zero as reported in Lindner-Lunsford and Ellis (1984) was replaced with a value of 0.25 to avoid having to use $\log (0)$ in calculation. 
No within-storm variations were studied, because the regression equations only simulate storm-runoff volumes, peak flows, and storm-runoff loads. The number of dry days between storms was used as one of the independent variables, and this number could be considered to be a rudimentary form of continuity in the simulation.

\section{Data Requirements}

Data requirements for the two types of models were different. The multievent, conceptually based models require detailed understanding of the storms and of the basin characteristics. The data required by the multievent, conceptually based models for detailed simulation include: (1) Incremental rainfall during storms and daily rainfall for periods between storms; (2) soil-moisture and infiltration parameter values; (3) area and percentage of effective impervious area of each subbasin within the basin; (4) extensive physical descriptions of the drainage features of the basin in terms of a series of overland flow planes and a channel drainage network, characterized by mean slope, roughness, and overland-flow path length; (5) impervious retention, the depth of rainfall retained on impervious surfaces; and (6) water-quality-constituent accumulation and washoff parameter values. (Effective impervious areas are those impervious areas that are hydraulically connected to either the channel drainage system or to other effective impervious areas, such as a roof that drains onto driveways, streets, sidewalks, or paved parking lots. A concrete slab that drains onto a lawn would be an example of an area that is not effectively impervious.) Physical characteristics of the study basins and detailed aerial photographs of the basins showing the superimposed subbasin boundaries and channel network, 5-minute rainfall and runoff data, and runoff water-quality analyses are published in Gibbs (1981) and Gibbs and Doerfer (1982).

The single-event, multiple-linear regression models were designed to use only readily available data summarizing storms. Models were designed not to require any extensive field work to characterize basins. Therefore, data requirements for the regression models were extremely simple. The only independent variables that were determined to be significant at a 95-percent level of confidence as determined by an F-test were: (1) Total rainfall, (2) maximum rainfall intensity for any 5-minute period during the storm, (3) duration of storm, and (4) number of antecedent dry days (less than 0.01 inch of precipitation). Not all of these variables were significant for all of the models. The coefficients derived for each of the equations are listed in table 2 .

The first five data items required for the multievent, conceptually based models were used to simulate runoff with $\mathrm{DR}_{3} \mathrm{M}-\mathrm{II}$. Measured-runoff hydrographs and water-quality-constituent accumulation and washoff parameters (item 6), were used to produce load estimates with $\mathrm{DR}_{3} \mathrm{M}-\mathrm{QUAL}$. Because the soilmoisture, infiltration, and constituent-accumulation and washoff-parameter values are so difficult to measure, they virtually became empirically determined model-calibration parameters. These parameters were adjusted during model calibration by a combination of manual and automatic procedures (Lindner-Lunsford and Ellis, 1984). Although simulated runoff hydrographs from $\mathrm{DR}_{3} \mathrm{M}$-II could be used with the quality model, measured runoff data were used so that the input errors would be the same as the regression models. 
Implementation Time

Possibly the most noticeable difference between the multievent, conceptually based models and the single-event regression models is in the time necessary to implement the two types of models. Time required for the user to become familiar with the models is greater for the more complex conceptually based models. Data-collection costs, such as installation and maintainance of a rain gage, runoff measurement, and water-quality sample collection and analysis, would be the same in either instance. The conceptually based models require development of physical descriptions of the basin as discussed in the previous section; the regression models developed in this study require no such data. In addition, the regression model using the SAS procedure required only one computer run to develop, whereas the conceptually based models required many runs and trial-and-error adjustment of parameters to achieve a best fit. In fact, although an objective function can be defined (Alley and Smith, 1982a), there is no absolute criterion of when the "best fit" for the conceptually based model has been achieved. The automatic optimization methods used in the model may stop at a local optimum, rather than the global minimum value of the objective function (W. M. Alley, U.S. Geological Survey, oral commun., 1985).

\section{Detail of Results}

One advantage of the multievent, conceptually based models is the detail of results. $\mathrm{DR}_{3} \mathrm{M}$-II provided a hydrograph at the outlet of the basin showing simulated flow in 5-minute increments throughout the duration of the storm and is capable of providing similar hydrographs for each subbasin in the basin. However, the single-event regression models only are able to predict stormrunoff volume and peak flow. Similar contrasts in the degree of detail produced were found in the predictions of storm-runoff loads. The conceptually based model produced: (1) Simulation of storm-runoff loads based on impervious area, pervious area, and precipitation contributions to runoff quality; (2) tables of time versus simulated discharge and water-quality constituent concentration for each storm; and (3) daily accounting of waterquality-constituent accumulation and washoff on effective impervious surfaces for periods between the storms of interest. The regression model, REG-QUAL, only predicted total storm-runoff loads.

\section{Transferability}

Ideally, the multievent, conceptually based models would be usable for an ungaged basin if soil-moisture and water-quality-constituent accumulation and washoff parameter values for the basin were known or could be derived by analogy to other similar basins, and physical descriptions of the drainage characteristics of the basin were available. In practice, soil-moisture parameters should have little effect on simulated storm-runoff volumes and peak flows for fairly urbanized basins. However, the other physical parameters are so difficult to measure that they virtually are model-calibration parameters and, hence, are not transferable. The single-event, multiple linear-regression models presented here were developed on a site-specific 
basis and, hence, are not transferable; however, Ellis and others (1984) developed regression equations that may be transferable to other similar basins.

\section{COMPARISON OF MODEL RESULTS}

Neither type of model was consistently more accurate than the other in simulating a storm characteristic or particular constituent, nor was one type of model more accurate than the other when applied to a particular basin. Five statistical measures of error were used to compare the results from the multievent, conceptually based models and single-event, multiple linearregression models: total percentage difference, root-mean-square error (RMSE) of the untransformed and log-transformed values, and mean absolute deviation (MAD) of the untransformed and log-transformed values. Total percentage difference is the percentage difference between the sum of the measured and the simulated values, a measure of how well the simulating procedure can simulate storm-runoff volumes and peak flows, or storm-runoff loads from a series of storms. RMSE and MAD are measures of how well the simulating procedure simulated individual storm-runoff volumes, peak flows, or stormrunoff loads. Both untransformed and log-transformed measured and simulated values were used to calculate RMSE and MAD values.

In several instances, the various error data indicate contradictory conclusions. Usually this can be explained by the occurrence of one or two storms that are outliers compared to the others in the data set. Because the log-transformations tend to give less weight to large outlying values and proportionately more weight to small values than the untransformed statistics give, the log-transformed RMSE or MAD values can indicate that $\mathrm{DR}_{3} \mathrm{M}-\mathrm{II}$ is a better predictor than REG for a particular characteristic, whereas the untransformed RMSE or MAD values can indicate the opposite. Storm-by-storm examination is needed in these instances. Detailed discussions of the model results for the four basins follow.

\section{North Avenue Basin}

In the North Avenue basin, 32 storms were monitored for rainfall and runoff. Of these storms, 17 were chosen for the calibration data set and 15 for the verification data set. A comparison of the estimates of storm-runoff volumes and peak flows of the calibration and verification data sets for the conceptually based and regression flow models is presented in tables 3 and 4. Simulated values of storm-runoff volume and peak flow are plotted against measured values for the verification data set in figure 2 . Both $D_{3} M-I I$ and REG were able to simulate runoff volumes fairly well. Both methods were capable of simulating a seasonal or yearly series of storm-runoff volumes or the volumes of individual storms with about the same degree of accuracy. $\mathrm{DR}_{3} \mathrm{M}-\mathrm{II}$ was not as accurate as REG for estimates of peak flows from individual storms, as demonstrated by the larger RMSE and MAD values for both the untransformed and log-transformed values for $\mathrm{DR}_{3} \mathrm{M}-\mathrm{II}$ than for REG (table 3 ). (Peak flows from storms of less than 0.01 inch of runoff were not simulated because there were difficulties in measuring these flows during the earlier phase of the study.) However, both methods probably are accurate enough to obtain peak-flow data for planning purposes. 
Table 3.--Comparison of conceptually based and regression flow-model calibration results for the North Avenue basin

[Storm-runoff volume is in inches; peak flow is in cubic feet per second; dashes indicate not used for calibration]

\begin{tabular}{|c|c|c|c|c|c|c|}
\hline \multirow{3}{*}{ Storm date } & \multicolumn{3}{|c|}{ Storm-runoff volume } & \multicolumn{3}{|c|}{ Peak flow } \\
\hline & \multirow[t]{2}{*}{ Measured } & \multicolumn{2}{|c|}{ Simulated } & \multirow[t]{2}{*}{ Measured } & \multicolumn{2}{|c|}{ Simulated } \\
\hline & & $\overline{\mathrm{DR}_{3} \mathrm{M}-\mathrm{II}}$ & REG & & $\mathrm{DR}_{3} \mathrm{M}-\mathrm{II}$ & $\mathrm{REG}$ \\
\hline \multicolumn{7}{|l|}{1980} \\
\hline May $11,-$ & 0.03 & 0.02 & 0.01 & 2.1 & 0.44 & 0.89 \\
\hline May $15-16-\ldots$ & .23 & .18 & .18 & 3.8 & 4.8 & 3.2 \\
\hline July $24-\cdots$ & .04 & .03 & .03 & 2.8 & 1.4 & 5.2 \\
\hline September 8-9- & .33 & .24 & .28 & 5.1 & 5.0 & 4.9 \\
\hline September $10^{1}$ & .02 & .02 & .02 & .99 & .93 & .92 \\
\hline September 20 & .06 & .06 & .06 & 4.1 & 5.2 & 4.4 \\
\hline \multicolumn{7}{|l|}{$\underline{1981}$} \\
\hline April 19-20- & .08 & .11 & .12 & 5.1 & 2.5 & 3.8 \\
\hline May $3^{1} \ldots$ & .05 & .06 & .06 & 1.7 & 2.0 & 2.4 \\
\hline 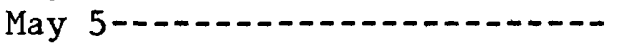 & .01 & .01 & .02 & -- & - & -- \\
\hline May $17-18-1$ & .25 & .27 & .29 & 2.4 & 2.8 & 4.0 \\
\hline May 28 & .01 & .01 & .01 & -- & -- & -- \\
\hline June $2-3-1-1-1$ & .07 & .08 & .08 & 4.1 & 5.4 & 3.6 \\
\hline 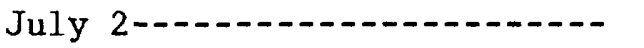 & .03 & .02 & .03 & 2.4 & 1.1 & 2.1 \\
\hline July $22-\cdots$ & .01 & .01 & .01 & -- & -- & -- \\
\hline August $9-10$ & .14 & .14 & .15 & 9.4 & 9.2 & 8.2 \\
\hline August $12-13$ & .04 & .05 & .04 & 4.9 & 4.5 & 4.3 \\
\hline September 6-7 & .06 & .04 & .05 & 1.7 & 1.2 & 2.2 \\
\hline Mean-n--n & .09 & .08 & .09 & 3.6 & 3.3 & 3.6 \\
\hline Total percentage difference-- & & -7.5 & -.96 & & -8.1 & -1.2 \\
\hline \multicolumn{7}{|l|}{ Root-mean-square error (RMSE) } \\
\hline Untransformed, in percent-- & & 27 & 27 & & 32 & 27 \\
\hline $\begin{array}{l}\text { Log-transformed, in log units } \\
\text { Natural-log-transformed, in } \\
\text { natural log units (LN) }\end{array}$ & & $\begin{array}{l}.104 \\
.240\end{array}$ & $\begin{array}{l}.122 \\
.280\end{array}$ & & $\begin{array}{l}.236 \\
.542\end{array}$ & $\begin{array}{r}.163 \\
.375\end{array}$ \\
\hline \multicolumn{7}{|l|}{ Mean absolute deviation (MAD) } \\
\hline $\begin{array}{l}\text { Untransformed, in same units } \\
\text { as measured data. }\end{array}$ & & 0.016 & 0.016 & & 0.880 & 0.826 \\
\hline Log-transformed, in $\log$ units & & .077 & .090 & & .166 & .118 \\
\hline
\end{tabular}

${ }^{1}$ First storm. 
Table 4.--Comparison of conceptually based and regression flow-model verification results for the North Avenue basin

[Storm-runoff volume is in inches; peak flow is in cubic feet per second; dashes indicate not used for verification]

\begin{tabular}{|c|c|c|c|c|c|c|}
\hline \multirow{3}{*}{ Storm date } & \multicolumn{3}{|c|}{ Storm-runoff volume } & \multicolumn{3}{|c|}{ Peak flow } \\
\hline & \multirow{2}{*}{ Measured } & \multicolumn{2}{|c|}{ Simulated } & \multirow{2}{*}{ Measured } & \multicolumn{2}{|c|}{ Simulated } \\
\hline & & $\overline{\mathrm{DR}_{3} \mathrm{M}-\mathrm{II}}$ & REG & & $\mathrm{DR}_{3} \mathrm{M}-\mathrm{II}$ & REG \\
\hline \multicolumn{7}{|l|}{$\underline{1980}$} \\
\hline May 8 & 0.12 & 0.06 & 0.07 & 2.8 & 2.4 & 2.4 \\
\hline May 12 & .01 & .01 & .01 & - & - & - \\
\hline May $17-1$ & .16 & .10 & .08 & 2.6 & 2.3 & 1.5 \\
\hline August 10 & .01 & .01 & .01 & -- & -- & -- \\
\hline September 10 & .03 & .06 & .04 & 7.0 & 8.9 & 7.3 \\
\hline \multicolumn{7}{|l|}{1981} \\
\hline March $3-\cdots$ & .03 & .03 & .05 & 1.1 & .77 & 1.2 \\
\hline April 20 & .02 & .02 & .02 & 2.8 & 1.2 & 4.0 \\
\hline May $3^{1} \ldots \ldots$ & .02 & .04 & .04 & 1.3 & 1.7 & 2.1 \\
\hline May $9-10-0$ & .09 & .11 & .12 & 3.1 & 6.0 & 3.9 \\
\hline May 16 & .03 & .03 & .04 & .82 & .55 & 1.1 \\
\hline May $28-29$ & .07 & .07 & .06 & 2.5 & 2.0 & 2.4 \\
\hline July $15 \cdots$ & .05 & .06 & .06 & 11 & 7.4 & 11 \\
\hline August 12 & .02 & .01 & .02 & 1.5 & .71 & .92 \\
\hline August 16 & .01 & .01 & .01 & -- & -- & -- \\
\hline August 31 & .01 & .01 & .01 & -- & -- & -- \\
\hline Mean- & .04 & .04 & .04 & 3.3 & 3.1 & 3.4 \\
\hline Total percentage difference-- & & -5.9 & -1.5 & & -7.1 & 3.6 \\
\hline \multicolumn{7}{|l|}{ Root-mean-square error (RMSE) } \\
\hline Untransformed, in percent-- & & 42 & 43 & & 50 & 21 \\
\hline Log-transformed, in log units & & .17 & .14 & & .20 & .15 \\
\hline $\begin{array}{l}\text { Natural-log-transformed, in } \\
\text { natural log units (LN) }\end{array}$ & & .40 & .32 & & .46 & .34 \\
\hline \multicolumn{7}{|l|}{ Mean absolute deviation (MAD) } \\
\hline $\begin{array}{l}\text { Untransformed, in same units } \\
\text { as measured data. }\end{array}$ & & 0.014 & 0.015 & & 1.2 & 0.51 \\
\hline Log-transformed, in $\log$ units & & .10 & .10 & & .17 & .11 \\
\hline
\end{tabular}

${ }^{1}$ Second storm. 

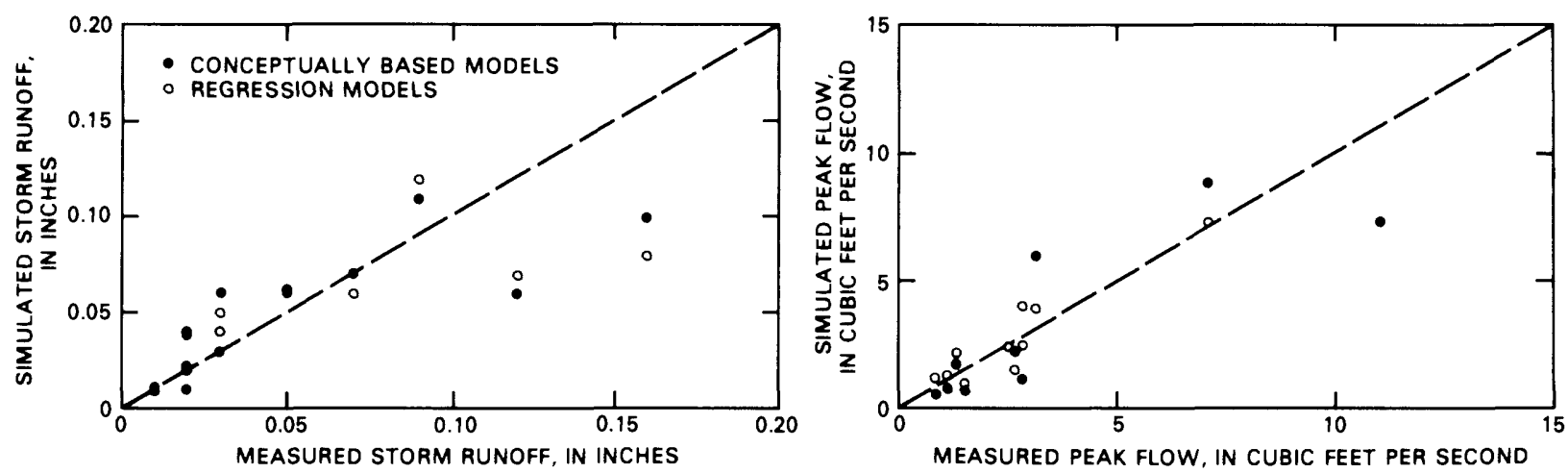

Figure 2.--Simulated versus measured storm-runoff volumes and peak flows for the verification data set for the North Avenue basin.

The water-quality models for the North Avenue basin were calibrated using data from 9 storms and verified using data from 11 storms. Comparisons of measured values of storm-runoff loads and simulated values produced by $\mathrm{DR}_{3} \mathrm{M}-\mathrm{QUAL}$ and by REG-QUAL are presented in tables 5 and 6 . Measured values of storm-runoff loads and simulated storm-runoff loads for selected constituents for the verification data set are plotted in figure 3 . The two models were about equally accurate in simulating the sum of storm-runoff loads of total suspended solids, total phosphorus, total lead, and total zinc. (Compare "total percentage difference" values in table 6 for the two models.) $\mathrm{DR}_{3} \mathrm{M}-\mathrm{QUAL}$ was a more accurate simulator of total manganese; REG-QUAL produced noticeably better results for storm-runoff loads of chemical oxygen demand and total nitrogen. However, REG-QUAL also was a more accurate (based on the test statistics in table 6) simulator of individual storm-runoff loads than $\mathrm{DR}_{3} \mathrm{M}$-QUAL for chemical oxygen demand, total suspended solids, and total nitrogen. For total phosphorus, total lead, total manganese, and total zinc, the RMSE and MAD data indicate conflicting evaluations of which model produced more accurate results.

\section{Northglenn Basin}

In the Northglenn basin, 23 storms were monitored for rainfall and runoff, of which 13 were selected for the calibration data set and 10 for the verification data set. Comparisons of the storm-runoff volumes and peak flows simulated by the two models for the calibration and verification data sets are 
Table 5.--Comparison of conceptually based and regression

[Measured and simulated

\begin{tabular}{|c|c|c|c|c|c|c|c|c|c|}
\hline \multirow{3}{*}{ Storm date } & \multicolumn{3}{|c|}{ Chemical oxygen demand } & \multicolumn{3}{|c|}{ Total suspended solids } & \multicolumn{3}{|c|}{ Total nitrogen as $\mathrm{N}$} \\
\hline & \multirow[b]{2}{*}{ Measured } & \multicolumn{2}{|c|}{ Simulated } & \multirow[b]{2}{*}{ Measured } & \multicolumn{2}{|c|}{ Simulated } & \multirow[b]{2}{*}{ Measured } & \multicolumn{2}{|c|}{ Simulated } \\
\hline & & $\begin{array}{l}\mathrm{DR}_{3} \mathrm{M-}- \\
\text { QUAL }\end{array}$ & $\begin{array}{l}\text { REG- } \\
\text { QUAL }\end{array}$ & & $\begin{array}{l}\mathrm{DR}_{3} \mathrm{M}- \\
\text { QUAL }\end{array}$ & $\begin{array}{l}\text { REG- } \\
\text { QUAL }\end{array}$ & & $\begin{array}{l}\mathrm{DR}_{3} \mathrm{M}^{-} \\
\text {QUAL }\end{array}$ & $\begin{array}{l}\text { REG- } \\
\text { QUAL }\end{array}$ \\
\hline \multicolumn{10}{|l|}{$\underline{1980}$} \\
\hline May 8 & - 190 & 150 & 170 & 1,200 & 480 & 880 & 6.8 & 4.1 & 4.7 \\
\hline May 11 & - 110 & 80 & 84 & 240 & 240 & 240 & 2.4 & 2.0 & 1.8 \\
\hline May $12 \ldots$ & 31 & 28 & 63 & 100 & 88 & 120 & .77 & .73 & .88 \\
\hline May $15-16$ & - 260 & 210 & 320 & 1,100 & 660 & 1,600 & 7.8 & 5.8 & 8.8 \\
\hline July 24 & - 120 & 160 & 120 & 190 & 420 & 210 & 4.0 & 4.1 & 2.9 \\
\hline September $8-9$ & - 470 & 600 & 440 & 690 & 1,600 & 660 & 13 & 16 & 12 \\
\hline September $10^{1} \ldots$ & 94 & 39 & 90 & 300 & 120 & 260 & 1.3 & 1.0 & 2.0 \\
\hline \multicolumn{10}{|l|}{$\underline{1981}$} \\
\hline June $2-3$ & - 200 & 160 & 200 & 510 & 460 & 510 & 3.4 & 4.1 & 5.3 \\
\hline July 15 & - 160 & 200 & 150 & 940 & 680 & 930 & 2.3 & 5.1 & 4.1 \\
\hline Mean-- & - 180 & 180 & 180 & 590 & 530 & 600 & 4.6 & 4.8 & 4.7 \\
\hline $\begin{array}{l}\text { Total percentage } \\
\text { difference- }\end{array}$ & & 0 & 0 & & -10 & 3 & & 3 & 0.48 \\
\hline \multicolumn{10}{|l|}{$\frac{\text { Root-mean-square }}{\text { error (RMSE) }}$} \\
\hline $\begin{array}{l}\text { Untransformed, in } \\
\text { percent. }\end{array}$ & & 29 & 17 & & 74 & 39 & & 43 & 29 \\
\hline $\begin{array}{l}\text { Log-transformed, } \\
\text { in } \log \text { units. }\end{array}$ & & .162 & .106 & & .280 & .089 & & .176 & .121 \\
\hline $\begin{array}{l}\text { Natural-log- } \\
\text { transformed, } \\
\text { in natural } \\
\text { log units (LN). }\end{array}$ & & .374 & .243 & & .645 & .206 & & .406 & .353 \\
\hline \multicolumn{10}{|l|}{$\frac{\text { Mean absolute }}{\text { deviation (MAD) }}$} \\
\hline $\begin{array}{l}\text { Untransformed, in } \\
\text { same units as } \\
\text { measured data. }\end{array}$ & & 48 & 21 & & 310 & 110 & & 1.34 & 1.18 \\
\hline $\begin{array}{l}\text { Log-transformed, } \\
\text { in log units. }\end{array}$ & & .132 & .072 & & .218 & .058 & & .153 & .135 \\
\hline
\end{tabular}

${ }^{1}$ First storm. 
quality-model calibration results for the North Avenue basin

values are loads, in pounds]

\begin{tabular}{|c|c|c|c|c|c|c|c|c|c|c|c|}
\hline \multicolumn{3}{|c|}{ Total phosphorus as $\mathrm{P}$} & \multicolumn{3}{|c|}{ Total lead } & \multicolumn{3}{|c|}{ Total manganese } & \multicolumn{3}{|c|}{ Total zinc } \\
\hline \multirow{2}{*}{ Measured } & & \multirow[b]{2}{*}{ Measured } & \multicolumn{2}{|c|}{ Simulated } & \multirow{2}{*}{ Measured } & \multicolumn{2}{|c|}{ Simulated } & \multirow[b]{2}{*}{ Measured } & \multicolumn{2}{|c|}{ Simulated } \\
\hline & $\begin{array}{l}\mathrm{DR}_{3} \mathrm{M}^{-} \\
\mathrm{QUAL}\end{array}$ & $\begin{array}{l}\text { REG- } \\
\text { QUAL }\end{array}$ & & $\begin{array}{l}\mathrm{DR}_{3} \mathrm{M}^{-} \\
\text {QUAL }\end{array}$ & $\begin{array}{l}\text { REG- } \\
\text { QUAL }\end{array}$ & & $\begin{array}{l}\mathrm{DR}_{3} \mathrm{M-} \\
\mathrm{QUAL}\end{array}$ & $\begin{array}{l}\text { REG- } \\
\text { QUAL }\end{array}$ & & $\begin{array}{l}\mathrm{DR}_{3} \mathrm{M}^{-} \\
\text {QUAL }\end{array}$ & $\begin{array}{l}\text { REG- } \\
\text { QUAI }\end{array}$ \\
\hline 1.2 & 0.47 & 0.66 & 0.38 & 0.21 & 0.25 & 0.90 & 0.27 & 0.64 & 0.47 & 0.27 & 0.36 \\
\hline .24 & .28 & .42 & .13 & .12 & .16 & .21 & .18 & .16 & .24 & .18 & .21 \\
\hline .09 & .10 & .36 & .04 & .04 & .13 & .05 & .06 & .08 & .07 & .06 & .17 \\
\hline 1.1 & .61 & 1.1 & .49 & .27 & .41 & .88 & .33 & 1.2 & .59 & .33 & .61 \\
\hline .41 & .62 & .50 & .16 & .22 & .19 & .21 & .30 & .19 & .22 & .30 & .26 \\
\hline 1.2 & 1.9 & 1.4 & .44 & .73 & .54 & .57 & .84 & .65 & .77 & .84 & .80 \\
\hline .32 & .13 & .43 & .14 & .06 & .16 & .20 & .09 & .18 & .14 & .09 & .22 \\
\hline .51 & .53 & .72 & .25 & .23 & .28 & .40 & .30 & .43 & .33 & .30 & .39 \\
\hline 1.1 & 1.0 & .61 & .32 & .36 & .23 & .64 & .46 & .71 & .51 & .46 & .32 \\
\hline .69 & .63 & .69 & .26 & .25 & .26 & .45 & .31 & .47 & .37 & .31 & .37 \\
\hline & -8.6 & 0 & & -4.7 & 0 & & -30 & 5 & & -15 & 0 \\
\hline & 62 & 35 & & 60 & 28 & & 49 & 37 & & 31 & 25 \\
\hline & .240 & .122 & & .210 & .112 & & .230 & .117 & & .137 & .113 \\
\hline & .553 & .282 & & .482 & .258 & & .530 & .270 & & .316 & .260 \\
\hline & 0.277 & 0.235 & & 0.099 & 0.066 & & 0.219 & 0.101 & & 0.090 & 0.074 \\
\hline & .178 & .200 & & .152 & .141 & & .226 & .092 & & .126 & .127 \\
\hline
\end{tabular}


Table 6.--Comparison of conceptually based and regression

[Measured and simulated values are loads, in

\begin{tabular}{|c|c|c|c|c|c|c|c|c|c|}
\hline \multirow{3}{*}{ Storm date } & \multicolumn{3}{|c|}{ Chemical oxygen demand } & \multicolumn{3}{|c|}{ Total suspended solids } & \multicolumn{3}{|c|}{ Total nitrogen as $\mathrm{N}$} \\
\hline & \multirow{2}{*}{ Measured } & \multicolumn{2}{|c|}{ Simulated } & \multirow{2}{*}{ Measured } & \multicolumn{2}{|c|}{ Simulated } & \multirow{2}{*}{ Measured } & \multicolumn{2}{|c|}{ Simulated } \\
\hline & & $\begin{array}{l}\mathrm{DR}_{3} \mathrm{M}^{-} \\
\text {QUAL }\end{array}$ & $\begin{array}{l}\text { REG- } \\
\text { QUAL }\end{array}$ & & $\begin{array}{l}\text { DR }{ }_{3}^{M-} \\
\text { QUAL }\end{array}$ & $\begin{array}{l}\text { REG- } \\
\text { QUAL }\end{array}$ & & $\begin{array}{l}\mathrm{DR}_{3} \mathrm{M}^{-} \\
\text {QUAL }\end{array}$ & $\begin{array}{l}\text { REG- } \\
\text { QUAL }\end{array}$ \\
\hline \multicolumn{10}{|l|}{$\underline{1981}$} \\
\hline May 5 & 83 & 45 & 90 & 100 & 130 & 150 & 1.2 & 1.2 & 1.9 \\
\hline May 9 & - 140 & 380 & 250 & 310 & 1,100 & 550 & 5.4 & 9.9 & 6.8 \\
\hline May $16-10$ & -100 & 120 & 120 & 150 & 340 & 150 & 2.3 & 3.0 & 3.0 \\
\hline May $26-29-$ & -160 & 220 & 160 & 400 & 620 & 820 & 3.3 & 5.7 & 4.4 \\
\hline July 2-- & -140 & 96 & 110 & 210 & 250 & 180 & 4.3 & 2.4 & 2.7 \\
\hline July 22-1- & 95 & 56 & 74 & 89 & 150 & 74 & 2.6 & 1.4 & 1.3 \\
\hline July $26-27-\cdots$ & - 580 & 740 & 580 & 2,700 & 2,000 & 2,800 & 13 & 19 & 15 \\
\hline Aug. $12-$ & 94 & 69 & 90 & 150 & 200 & 110 & 1.8 & 1.8 & 1.9 \\
\hline Aug. 12-13- & - 120 & 150 & 130 & 370 & 430 & 890 & 2.1 & 3.9 & 3.4 \\
\hline Aug. 16 & - --- & -- & -- & 22 & 61 & 76 & .64 & .54 & 1.1 \\
\hline Aug. 29- & 44 & 85 & 63 & 35 & 220 & 33 & .92 & 2.2 & .88 \\
\hline 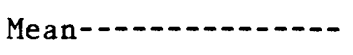 & 160 & 200 & 170 & 410 & 500 & 530 & 3.4 & 4.6 & 3.9 \\
\hline $\begin{array}{l}\text { Total percentage } \\
\text { difference- }\end{array}$ & & 26 & 7 & & 21 & 29 & & 36 & 13 \\
\hline \multicolumn{10}{|l|}{$\frac{\text { Root-mean-square }}{\text { error (RMSE) }}$} \\
\hline $\begin{array}{l}\text { Untransformed, in } \\
\text { percent. }\end{array}$ & & 54 & 26 & & 61 & 49 & & 50 & 31 \\
\hline $\begin{array}{l}\text { Log-transformed, } \\
\text { in log units. }\end{array}$ & & .24 & .12 & & .20 & .23 & & .23 & .17 \\
\hline $\begin{array}{l}\text { Natural-log- } \\
\text { transformed, } \\
\text { in natural } \\
\text { log units }(\mathrm{LN})\end{array}$ & & .56 & .27 & & .47 & .53 & & .52 & .40 \\
\hline \multicolumn{10}{|l|}{$\frac{\text { Mean absolute }}{\text { deviation (MAD) }}$} \\
\hline $\begin{array}{l}\text { Untransformed, in } \\
\text { same units as } \\
\text { measured data. }\end{array}$ & & 70 & 22 & & 220 & 130 & & 1.8 & 0.96 \\
\hline $\begin{array}{l}\text { Log-transformed, } \\
\text { in } \log \text { units. }\end{array}$ & & .19 & .079 & & .28 & .18 & & .19 & .13 \\
\hline
\end{tabular}


quality-model verification results for the North Avenue basin

pounds, dashes indicate not used for verification]

\begin{tabular}{|c|c|c|c|c|c|c|c|c|c|c|c|}
\hline \multicolumn{3}{|c|}{ Total phosphorus as $\mathrm{P}$} & \multicolumn{3}{|c|}{ Total lead } & \multicolumn{3}{|c|}{ Total manganese } & \multicolumn{3}{|c|}{ Total zinc } \\
\hline \multirow[b]{2}{*}{ Measured } & \multicolumn{2}{|c|}{ Simulated } & \multirow[b]{2}{*}{ Measured } & \multicolumn{2}{|c|}{ Simulated } & \multirow[b]{2}{*}{ Measured } & \multicolumn{2}{|c|}{ Simulated } & \multirow[b]{2}{*}{ Measured } & \multicolumn{2}{|c|}{ Simulated } \\
\hline & $\begin{array}{l}\mathrm{DR}_{3} \mathrm{M}- \\
\text { QUAL }\end{array}$ & $\begin{array}{l}\text { REG- } \\
\text { QUAL }\end{array}$ & & $\begin{array}{l}\mathrm{DR}_{3} \mathrm{M}^{-} \\
\text {QUAL }\end{array}$ & $\begin{array}{l}\text { REG- } \\
\text { QUAL }\end{array}$ & & $\begin{array}{l}\mathrm{DR}_{3} \mathrm{MI}^{-} \\
\text {QUAL }\end{array}$ & $\begin{array}{l}\text { REG- } \\
\text { QUAL }\end{array}$ & & $\begin{array}{l}\mathrm{DR}_{3} \mathrm{M}^{-} \\
\text {QUAL }\end{array}$ & $\begin{array}{l}\text { REG- } \\
\text { QUAL }\end{array}$ \\
\hline 0.32 & 0.16 & 0.43 & 0.08 & 0.07 & 0.16 & 0.09 & 0.09 & 0.12 & 0.10 & 0.09 & 0.22 \\
\hline .62 & 1.4 & .87 & .25 & .54 & .33 & .26 & .73 & .49 & .30 & .73 & .48 \\
\hline .30 & .42 & .52 & .12 & .18 & .20 & .15 & .26 & .13 & .15 & .26 & .27 \\
\hline .54 & .72 & .64 & .20 & .28 & .24 & .38 & .38 & .59 & .27 & .38 & .34 \\
\hline .24 & .39 & .49 & .13 & .14 & .18 & .16 & .19 & .15 & .20 & .19 & .25 \\
\hline .17 & .22 & .39 & .06 & .08 & .14 & .10 & .12 & .062 & .11 & .12 & .19 \\
\hline 2.7 & 2.5 & 1.8 & .91 & .94 & .69 & 2.0 & 1.1 & 2.5 & 1.6 & 1.1 & 1.0 \\
\hline .37 & .25 & .43 & .08 & .10 & .16 & .12 & .15 & .091 & .13 & .15 & .22 \\
\hline .50 & .51 & .55 & .08 & .21 & .21 & .29 & .29 & .62 & .23 & .29 & .29 \\
\hline .04 & .08 & .37 & .02 & .03 & .14 & .027 & .047 & .061 & .034 & .047 & .18 \\
\hline .07 & .34 & .36 & .03 & .12 & .13 & .048 & .17 & .028 & .050 & .17 & .17 \\
\hline .53 & .64 & .63 & .18 & .24 & .23 & .33 & .32 & .42 & .29 & .32 & .33 \\
\hline & 19 & 18 & & 37 & 32 & & -2.7 & 33 & & 11 & 14 \\
\hline & 51 & 15 & & 50 & 14 & & 50 & 34 & & 52 & 19 \\
\hline & .24 & .11 & & .19 & .086 & & .18 & .21 & & .18 & .086 \\
\hline & .56 & .26 & & .44 & .20 & & .42 & .48 & & .42 & .20 \\
\hline & 0.19 & 0.24 & & 0.068 & 0.096 & & 0.15 & 0.13 & & 0.13 & 0.15 \\
\hline & .22 & .29 & & .20 & .32 & & .18 & .18 & & .18 & .28 \\
\hline
\end{tabular}



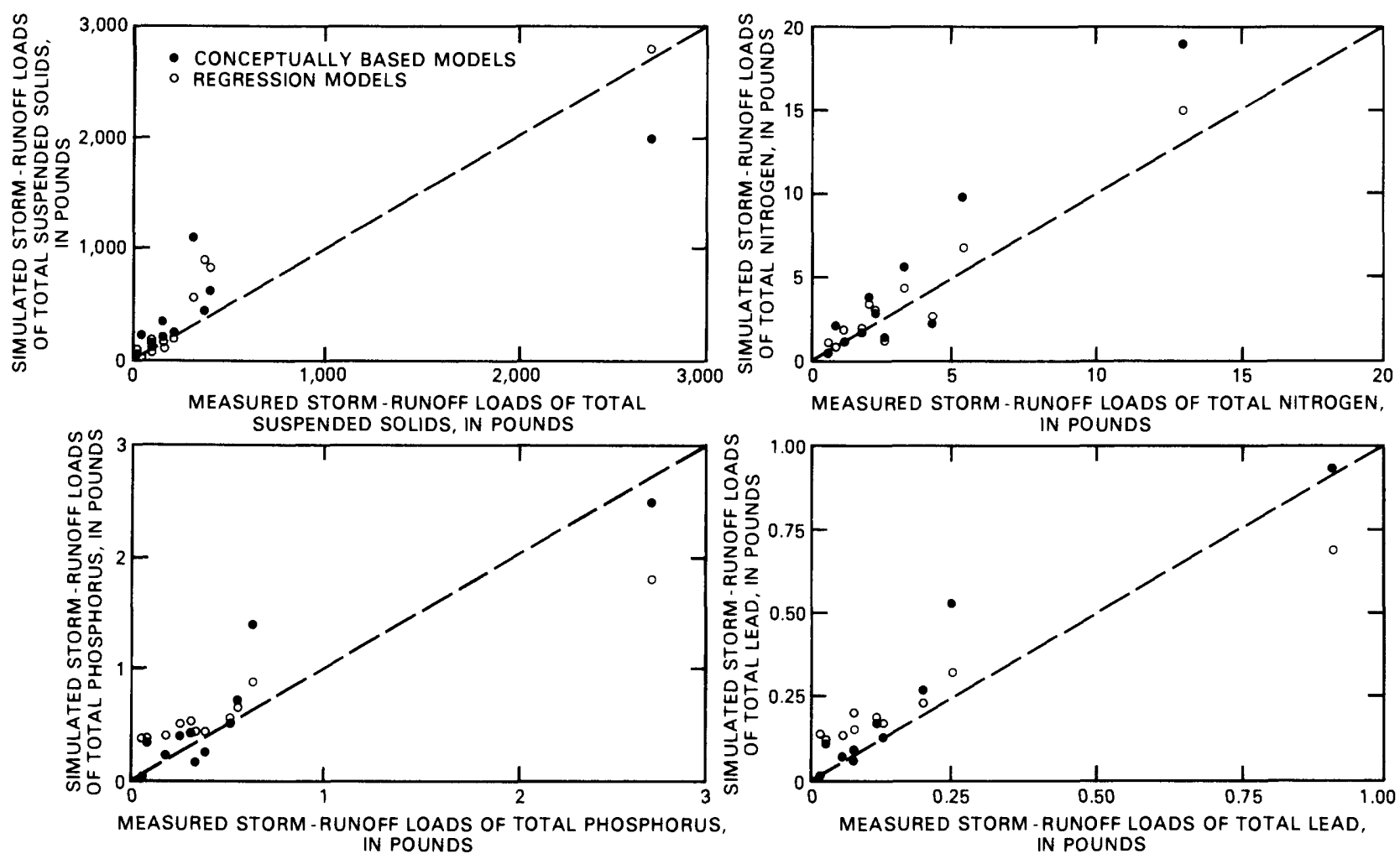

Figure 3.--Simulated versus measured storm-runoff loads for selected constituents for the verification data set for the North Avenue basin.

presented in tables 7 and 8 . Simulated storm-runoff volume and peak flow are plotted against the measured values for the verification data set in figure 4. $\mathrm{DR}_{3} \mathrm{M}$-II was a more accurate simulator of both storm-runoff volumes and peak flows than REG. The total percentage difference for storm-runoff volumes and peak flows was significantly smaller for $D_{3} M-I I$ than REG. Individual stormrunoff volumes simulated by the two models for all but the largest storms were comparable, although $\mathrm{DR}_{3} \mathrm{M}-\mathrm{II}$ had a slightly smaller MAD value. $\mathrm{DR}_{3} \mathrm{M}-\mathrm{II}$ was noticeably more accurate in simulating individual peak flows than was REG; $\mathrm{DR}_{3} \mathrm{M}-\mathrm{II}$ had much smaller RMSE and MAD values than did REG. However, much of the error was due to the fact that the regression model grossly underpredicted the storm of June 3, 1981.

Water-quality constituent-load data were available for only seven storms for this basin. Therefore, development of regression equations was not attempted.

\section{Cherry Knolls Basin}

In the Cherry Knolls basin, 13 storms were monitored for rainfall and runoff, of which 6 were selected for the calibration data set and 7 for the verification data set. A comparison of the measured values of storm-runoff volumes and peak flows with the simulated values predicted by $D R_{3} M-I I$ and $R E G$ 
Table 7.--Comparison of conceptually based and regression flow-model calibration results for the Northglenn basin

[Storm-runoff volume is in inches; peak flow is in cubic feet per second; dashes indicate not used for calibration]

\begin{tabular}{|c|c|c|c|c|c|c|}
\hline \multirow{3}{*}{ Storm date } & \multicolumn{3}{|c|}{ Storm-runoff volume } & \multicolumn{3}{|c|}{ Peak flow } \\
\hline & \multirow{2}{*}{ Measured } & \multicolumn{2}{|c|}{ Simulated } & \multirow{2}{*}{ Measured } & \multicolumn{2}{|c|}{ Simulated } \\
\hline & & $\overline{\mathrm{DR}_{3} \mathrm{M}-\mathrm{II}}$ & REG & & $\mathrm{DR}_{3} \mathrm{M}-\mathrm{II}$ & REG \\
\hline \multicolumn{7}{|l|}{$\underline{1980}$} \\
\hline May $8+\cdots$ & 0.02 & 0.02 & 0.02 & 3.0 & 3.4 & 3.2 \\
\hline May $11-1-1$ & .02 & .02 & .02 & 1.3 & 1.0 & 1.8 \\
\hline June 20 & .01 & .01 & .01 & -- & -- & -- \\
\hline August 15 & .06 & .07 & .06 & 7.0 & 7.8 & 10 \\
\hline September 20 & .06 & .08 & .07 & 11 & 13 & 14 \\
\hline \multicolumn{7}{|l|}{1981} \\
\hline May $3^{1}$ & .04 & .03 & .03 & 5.2 & 4.1 & 3.9 \\
\hline May $3^{2}$ & .08 & .09 & .06 & 29 & 27 & 24 \\
\hline May $12-13$ & .05 & .05 & .05 & 4.4 & 4.6 & 4.4 \\
\hline May $16-18 \ldots$ & .24 & .26 & .26 & 7.7 & 7.7 & 6.9 \\
\hline July $11 \cdots$ & .02 & .02 & .02 & 8.5 & 6.8 & 7.6 \\
\hline July 26 & .10 & .14 & .12 & 25 & 28 & 33 \\
\hline August 22 & .05 & .07 & .06 & 28 & 27 & 23 \\
\hline August 28 & .01 & .01 & .01 & -- & -- & -- \\
\hline Mean- & .06 & .07 & .06 & 12 & 12 & 12 \\
\hline Total percentage difference-- & & 14 & 5 & & 0.2 & 2.1 \\
\hline \multicolumn{7}{|l|}{ Root-mean-square error (RMSE) } \\
\hline Untransformed, in percent-- & & 20 & 15 & & 14 & 30 \\
\hline Log-transformed, in $\log$ units & & .071 & .085 & & .068 & .101 \\
\hline $\begin{array}{l}\text { Natural-log-transformed, in } \\
\text { natural log units (LN). } \\
\text { Mean absolute deviation (MAD) }\end{array}$ & & .163 & .196 & & .158 & .231 \\
\hline $\begin{array}{l}\text { Untransformed, in same units } \\
\text { as measured data. }\end{array}$ & & 0.010 & 0.008 & & 1.14 & 2.36 \\
\hline Log-transformed, in $\log$ units & & .053 & .075 & & .055 & .083 \\
\hline
\end{tabular}

${ }^{1}$ First storm.

${ }^{2}$ Second storm. 
Table 8.--Comparison of conceptually based and regression flow-model verification results for the Northglenn basin

[Storm-runoff volume is in inches; peak flow is in cubic feet per second; dashes indicate not used for verification]

\begin{tabular}{|c|c|c|c|c|c|c|}
\hline \multirow{3}{*}{ Storm date } & \multicolumn{3}{|c|}{ Storm-runoff volume } & \multicolumn{3}{|c|}{ Peak flow } \\
\hline & \multirow[t]{2}{*}{ Measured } & \multicolumn{2}{|c|}{ Simulated } & \multirow[t]{2}{*}{$\overline{\text { Measured }}$} & \multicolumn{2}{|c|}{ Simulated } \\
\hline & & $\overline{\mathrm{DR}_{3} \mathrm{M}-\mathrm{II}}$ & REG & & $\mathrm{DR}_{3} \mathrm{M}-\mathrm{II}$ & REG \\
\hline \multicolumn{7}{|l|}{1980} \\
\hline May $7-8$ & 0.27 & 0.20 & 0.16 & 17 & 14 & 11 \\
\hline July $1-2-\cdots$ & .02 & .03 & .03 & 5.0 & 3.7 & 3.8 \\
\hline July 2--nen & .07 & .09 & .07 & 30 & 36 & 22 \\
\hline August $25-26$ & .03 & .04 & .04 & 5.4 & 4.7 & 5.8 \\
\hline August $26-27$ & .06 & .07 & .06 & 16 & 18 & 15 \\
\hline \multicolumn{7}{|l|}{1981} \\
\hline April 19-20- & .05 & .07 & .06 & 6.6 & 5.3 & 6.5 \\
\hline June $3-0 .-1$ & .37 & .30 & .19 & ${ }^{1} 123$ & 140 & 49 \\
\hline July $12-1,-1$ & .01 & .01 & .01 & -- & -- & -- \\
\hline August $9-1$ & .05 & .05 & .05 & 18 & 15 & 17 \\
\hline August 16 & .01 & .01 & .02 & -- & -- & -- \\
\hline Mean-w- & .09 & .09 & .07 & 28 & 30 & 16 \\
\hline Total percentage difference-- & & -7.4 & -27 & & 7.2 & -41 \\
\hline \multicolumn{7}{|l|}{ Root-mean-square error (RMSE) } \\
\hline Untransformed, in percent-- & & 15 & 12 & & 9.4 & 14 \\
\hline Log-transformed, in $\log$ units & & .093 & .092 & & .060 & .088 \\
\hline $\begin{array}{l}\text { Natural-log-transformed, in } \\
\text { natural log units (LN) }\end{array}$ & & .22 & .21 & & .14 & .20 \\
\hline \multicolumn{7}{|l|}{ Mean absolute deviation (MAD) } \\
\hline $\begin{array}{l}\text { Untransformed, in same units } \\
\text { as measured data. }\end{array}$ & & 0.021 & 0.033 & & 4.3 & 11 \\
\hline Log-transformed, in $\log$ units & & .084 & .12 & & .080 & .12 \\
\hline
\end{tabular}

\footnotetext{
${ }^{1}$ Estimated.
} 

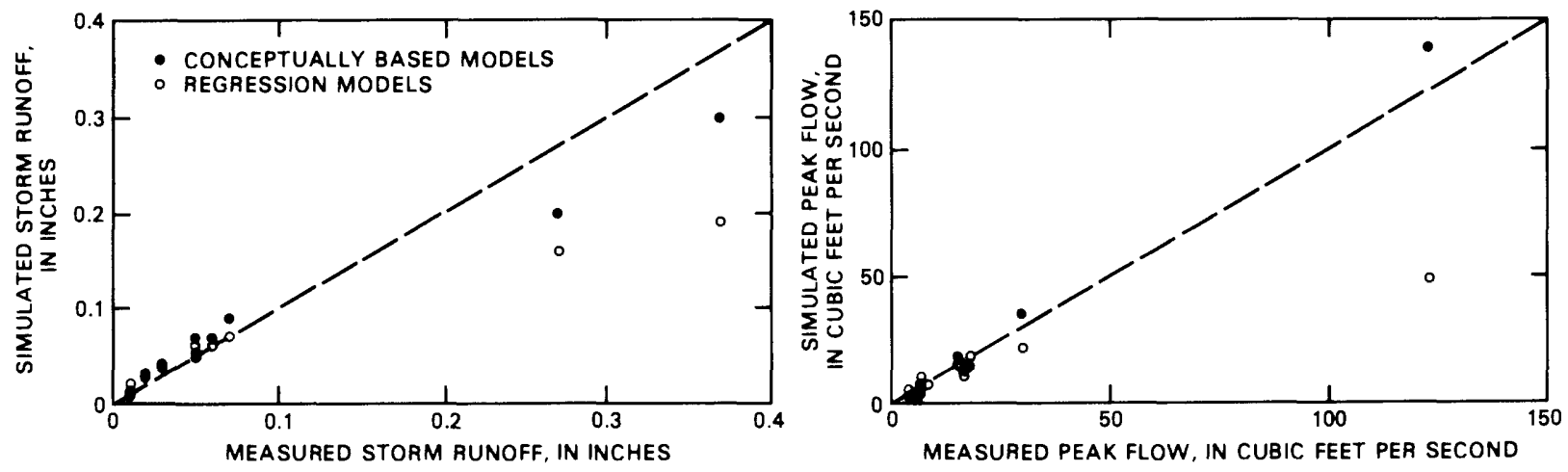

Figure 4.--Simulated versus measured storm-runoff volumes and peak flows for the verification data set for the Northglenn basin.

is presented in tables 9 and 10 and plotted in figure 5. REG had a smaller total percentage difference for storm-runoff volumes than did $\mathrm{DR}_{3} \mathrm{M}-\mathrm{II}$.

Individual storm-runoff volumes also seemed to be more accurately simulated by REG than by $D_{3} M-I I$; although the RMSE values were slightly larger for REG than for $D R_{3} M-I I$, the MAD values for $R E G$ were much smaller than the values for $\mathrm{DR}_{3} \mathrm{M}$-II for the untransformed and log-transformed data. Peak flows were somewhat more accurately simulated by $\mathrm{DR}_{3} \mathrm{M}-\mathrm{II}$; $\mathrm{DR}_{3} \mathrm{M}-\mathrm{II}$ had slightly smaller RMSE, MAD, and total percentage difference values for the untransformed and log-transformed data than did REG.
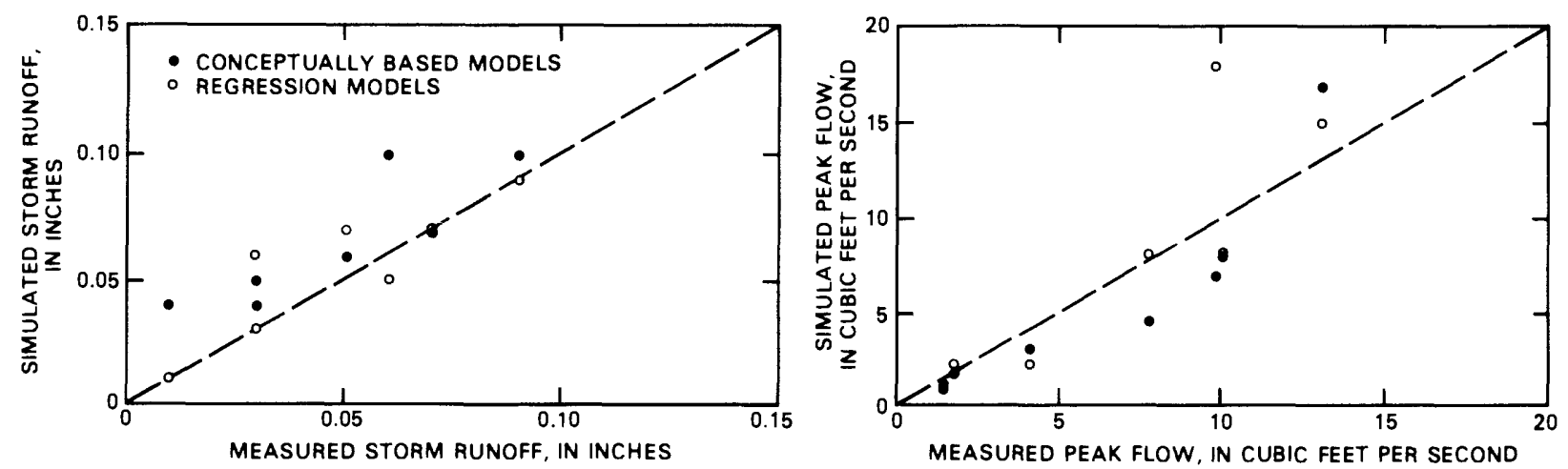

Figure 5.--Simulated versus measured storm-runoff values and peak flows for the verification data set for the Cherry Knolls basin.

Water-quality constituent data were available for eight storms for the Cherry Knolls basin. After calibration, $D_{3} \mathrm{M}-\mathrm{QUAL}$ was not able to be verified acceptably. Data that had been designated for the verification data set was included in the calibration data set, and the model was recalibrated, but no data were left for model verification. Therefore, the same procedure was followed for REG-QUAL, and all available data were added to the calibration data set. A comparison of the predictions of the two models with measured data is presented in table 11, and plotted in figure 6 for selected constituents. 
Table 9.--Comparison of conceptually based and regression flow-model calibration results for the Cherry Knolls basin

[Storm-runoff volume is in inches; peak flow is in cubic feet per second]

\begin{tabular}{|c|c|c|c|c|c|c|}
\hline \multirow{3}{*}{ Storm date } & \multicolumn{3}{|c|}{ Storm-runoff volume } & \multicolumn{3}{|c|}{ Peak flow } \\
\hline & \multirow[t]{2}{*}{ Measured } & \multicolumn{2}{|c|}{ Simulated } & \multirow[t]{2}{*}{ Measured } & \multicolumn{2}{|c|}{ Simulated } \\
\hline & & $\mathrm{DR}_{3} \mathrm{M}-\mathrm{II}$ & REG & & $\mathrm{DR}_{3} \mathrm{M}-\mathrm{II}$ & REG \\
\hline \multicolumn{7}{|l|}{1981} \\
\hline May $3^{1}$ & 0.02 & 0.02 & 0.02 & 2.6 & 2.0 & 2.2 \\
\hline May $27-28$ & .03 & .04 & .03 & 2.9 & 2.1 & 3.4 \\
\hline June $11-12-\cdots$ & .13 & .12 & .13 & 16 & 15 & 16 \\
\hline June 29 & .04 & .04 & .04 & 8.0 & 4.7 & 6.9 \\
\hline July $12-\cdots$ & .12 & .12 & .12 & 9.8 & 5.2 & 9.3 \\
\hline August $9-\ldots$ & .03 & .05 & .03 & 2.3 & 1.6 & 3.4 \\
\hline Mean-- & .06 & .06 & .06 & 6.9 & 5.1 & 6.9 \\
\hline Total percentage difference-- & & 5.4 & 0 & & -26 & 0 \\
\hline \multicolumn{7}{|l|}{ Root-mean-square error (RMSE) } \\
\hline Untransformed, in percent-- & & 14.4 & 2.7 & & 25 & 12.6 \\
\hline Log-transformed, in $\log$ units & & .097 & .025 & & .098 & .093 \\
\hline Natura1-log-transformed, in & & .223 & .057 & & .225 & .214 \\
\hline
\end{tabular}

Mean absolute deviation (MAD)

$\begin{array}{lllll}\text { Untransformed, in same units } & 0.00667 & 0.000951 & 1.833 & 0.6615 \\ \text { as measured data. } & & & & \\ \text { Log-transformed, in log units } & .0636 & .0413 & .1577 & .0673\end{array}$

${ }^{1}$ First storm. 
Table 10.--Comparison of conceptually based and regression flow-model verification results for the Cherry Knolls basin

[Storm-runoff volume is in inches; peak flow is in cubic feet per second]

\begin{tabular}{|c|c|c|c|c|c|c|}
\hline \multirow{3}{*}{ Storm date } & \multicolumn{3}{|c|}{ Storm-runoff volume } & \multicolumn{3}{|c|}{ Peak flow } \\
\hline & \multirow[t]{2}{*}{ Measured } & \multicolumn{2}{|c|}{ Simulated } & \multirow[t]{2}{*}{ Measured } & \multicolumn{2}{|c|}{ Simulated } \\
\hline & & $\overline{\mathrm{DR}_{3} \mathrm{M}-\mathrm{II}}$ & REG & & $\mathrm{DR}_{3} \mathrm{M}-\mathrm{II}$ & REG \\
\hline \multicolumn{7}{|l|}{1981} \\
\hline May $3^{1}-\ldots$ & 0.09 & 0.10 & 0.09 & 13 & 17 & 15 \\
\hline May $3-4-1-1$ & .01 & .04 & .01 & 1.8 & 1.7 & 2.2 \\
\hline May $12-13$ & .03 & .05 & .03 & 1.5 & 1.0 & .97 \\
\hline May 28 & .03 & .04 & .06 & 9.8 & 7.0 & 18 \\
\hline 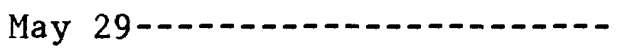 & .06 & .10 & .05 & 4.1 & 3.1 & 2.2 \\
\hline July $7-\cdots-1$ & .07 & .07 & .07 & 10 & 8.1 & 8.1 \\
\hline July $26-27-\ldots$ & .05 & .06 & .07 & 7.7 & 4.6 & 8.1 \\
\hline Mean-1-n & .05 & .07 & .05 & 6.8 & 6.1 & 7.8 \\
\hline Total percentage difference-- & & 35 & 12 & & -11 & 14 \\
\hline \multicolumn{7}{|l|}{ Root-mean-square error (RMSE) } \\
\hline Untransformed, in percent-- & & 29 & 30 & & 37 & 51 \\
\hline Log-transformed, in $\log$ unit & & .10 & .14 & & .12 & .18 \\
\hline $\begin{array}{l}\text { Natural-log transformed, in } \\
\text { natural log units (LN). }\end{array}$ & & .23 & .32 & & .28 & .42 \\
\hline \multicolumn{7}{|l|}{ Mean absolute deviation (MAD) } \\
\hline $\begin{array}{l}\text { Untransformed, in same units } \\
\text { as measured data. }\end{array}$ & & 0.017 & 0.0086 & & 1.9 & 2.2 \\
\hline Log-transformed, in $\log$ unit & & .19 & .075 & & .13 & .14 \\
\hline
\end{tabular}

${ }^{1}$ Second storm. 
Table 11.--Comparison of conceptually based and regression

[Measured and simulated

\begin{tabular}{|c|c|c|c|c|c|c|c|c|c|}
\hline \multirow{3}{*}{ Storm date } & Chemical & \multicolumn{2}{|c|}{ oxygen demand } & \multicolumn{3}{|c|}{ Total suspended solids } & \multicolumn{3}{|c|}{ Total nitrogen as $\mathrm{N}$} \\
\hline & \multirow[b]{2}{*}{ Measured } & \multicolumn{2}{|c|}{ Simulated } & \multirow[b]{2}{*}{ Measured } & \multicolumn{2}{|c|}{ Simulated } & \multirow[b]{2}{*}{ Measured } & \multicolumn{2}{|c|}{ Simulated } \\
\hline & & $\begin{array}{l}\mathrm{DR}_{3} \mathrm{M}- \\
\text { QUAL }\end{array}$ & $\begin{array}{l}\text { REG- } \\
\text { QUAL }\end{array}$ & & $\begin{array}{l}\mathrm{DR}_{3} \mathrm{M}- \\
\text { QUAL }\end{array}$ & $\begin{array}{l}\text { REG- } \\
\text { QUAL }\end{array}$ & & $\begin{array}{l}\mathrm{DR}_{3} \mathrm{M}^{-} \\
\text {QUAL }\end{array}$ & $\begin{array}{l}\text { REG- } \\
\text { QUAL }\end{array}$ \\
\hline \multicolumn{10}{|l|}{1981} \\
\hline May $12-\cdots$ & 18 & 32 & 19 & 14 & 40 & 1.5 & 0.85 & 1.2 & 1.3 \\
\hline May $17-18---\cdots-\cdots$ & 65 & 82 & 62 & 77 & 110 & 75 & 3.1 & 3.3 & 2.9 \\
\hline May 27-28-n- & 46 & 36 & 37 & 44 & 46 & 47 & .80 & 1.1 & .88 \\
\hline May 29-n- & 33 & 40 & 35 & 25 & 51 & 31 & 1.3 & 1.6 & 1.8 \\
\hline June $29-\ldots$ & 59 & 55 & 54 & 130 & 86 & 110 & 2.2 & 2.0 & 1.8 \\
\hline July $7-\cdots$ & 130 & 84 & 95 & 120 & 130 & 150 & 4.3 & 3.2 & 3.3 \\
\hline July $26-27 \ldots$ & 66 & 56 & 100 & 170 & 77 & 150 & 1.8 & 2.0 & 2.4 \\
\hline August 9 & 28 & 35 & 39 & 32 & 52 & 47 & .90 & 1.3 & .66 \\
\hline Mean- & 56 & 52 & 55 & 76 & 74 & 76 & 1.9 & 2.0 & 1.9 \\
\hline $\begin{array}{l}\text { Total percentage } \\
\text { difference- }\end{array}$ & & -5.6 & -0.90 & & -3.3 & 0.08 & & 3.2 & 0 \\
\hline \multicolumn{10}{|l|}{$\frac{\text { Root-mean-square }}{\text { error (RMSE) }}$} \\
\hline $\begin{array}{l}\text { Untransformed, in } \\
\text { percent- }\end{array}$ & & 21 & 31 & & 35 & 24 & & 9.7 & 21 \\
\hline $\begin{array}{l}\text { Log-transformed, } \\
\text { in log units. }\end{array}$ & & .083 & .11 & & .12 & .34 & & .035 & .12 \\
\hline $\begin{array}{l}\text { Natural-log- } \\
\text { transformed, } \\
\text { in natural } \\
\text { log units (LN). }\end{array}$ & & .19 & .25 & & .27 & .79 & & .080 & .28 \\
\hline \multicolumn{10}{|l|}{$\frac{\text { Mean absolute }}{\text { deviation (MAD) }}$} \\
\hline $\begin{array}{l}\text { Untransformed, in } \\
\text { same units as } \\
\text { measured data. }\end{array}$ & & 14 & 12 & & 32 & 14 & & 0.31 & 0.43 \\
\hline $\begin{array}{l}\text { Log-transformed } \\
\text { in log units. }\end{array}$ & & .12 & .083 & & .21 & .19 & & .088 & .11 \\
\hline
\end{tabular}


quality-model calibration results for the Cherry Knolls basin

values are loads, in pounds]

\begin{tabular}{|c|c|c|c|c|c|c|c|c|c|c|c|}
\hline \multicolumn{3}{|c|}{ Total phosphorus as $\mathrm{P}$} & \multicolumn{3}{|c|}{ Total lead } & \multicolumn{3}{|c|}{ Total manganese } & \multicolumn{3}{|c|}{ Total zinc } \\
\hline \multirow{2}{*}{ Measured } & \multicolumn{2}{|c|}{ Simulated } & \multirow[b]{2}{*}{ Measured } & \multicolumn{2}{|c|}{ Simulated } & \multirow[b]{2}{*}{ Measured } & \multicolumn{2}{|c|}{ Simulated } & \multirow[b]{2}{*}{ Measured } & \multicolumn{2}{|c|}{ Simulated } \\
\hline & $\begin{array}{l}\mathrm{DR}_{3} \mathrm{M}^{-} \\
\text {QUAL }\end{array}$ & $\begin{array}{l}\text { REG- } \\
\text { QUAL }\end{array}$ & & $\begin{array}{l}\mathrm{DR}_{3} \mathrm{M}- \\
\text { QUAL }\end{array}$ & $\begin{array}{l}\text { REG- } \\
\text { QUAL }\end{array}$ & & $\begin{array}{l}\mathrm{DR}_{3} \mathrm{M}^{-} \\
\text {QUAL }\end{array}$ & $\begin{array}{l}\text { REG- } \\
\text { QUAL }\end{array}$ & & $\begin{array}{l}\mathrm{DR}_{3} \mathrm{M}- \\
\text { QUAL }\end{array}$ & $\begin{array}{l}\text { REG- } \\
\text { QUAL }\end{array}$ \\
\hline 0.07 & 0.12 & 0.08 & 0.02 & 0.04 & 0.05 & 0.02 & 0.04 & 0.02 & 0.03 & 0.05 & 0.04 \\
\hline .48 & .37 & .46 & .08 & .10 & .07 & .06 & .12 & .06 & .11 & .16 & .10 \\
\hline .10 & .14 & .08 & .05 & .04 & .03 & .03 & .05 & .03 & .05 & .06 & .05 \\
\hline .14 & .18 & .16 & .04 & .05 & .06 & .03 & .06 & .04 & .06 & .08 & .06 \\
\hline .19 & .26 & .19 & .12 & .07 & .08 & .08 & .07 & .07 & .13 & .09 & .10 \\
\hline .77 & .42 & .56 & .16 & .11 & .14 & .14 & .12 & .14 & .19 & .15 & .19 \\
\hline .27 & .23 & .43 & .07 & .07 & .09 & .13 & .07 & .13 & .12 & .10 & .16 \\
\hline .06 & .15 & .06 & .02 & .05 & .02 & .03 & .04 & .03 & .04 & .06 & .04 \\
\hline .26 & .23 & .25 & .07 & .07 & .07 & .06 & .07 & .06 & .09 & .09 & .09 \\
\hline & -10 & -2.9 & & -5.4 & -3.6 & & 9.6 & 0 & & 2.7 & 1.4 \\
\hline & 14 & 32 & & 23 & 28 & & 41 & 8.5 & & 28 & 23 \\
\hline & .061 & .11 & & .11 & .18 & & .13 & .052 & & .092 & .080 \\
\hline & .14 & .25 & & .25 & .41 & & .30 & .12 & & .21 & .18 \\
\hline & 0.099 & 0.055 & & 0.024 & 0.020 & & 0.029 & 0.0025 & & 0.028 & 0.011 \\
\hline & .18 & .071 & & .17 & .15 & & .21 & .023 & & .14 & .051 \\
\hline
\end{tabular}



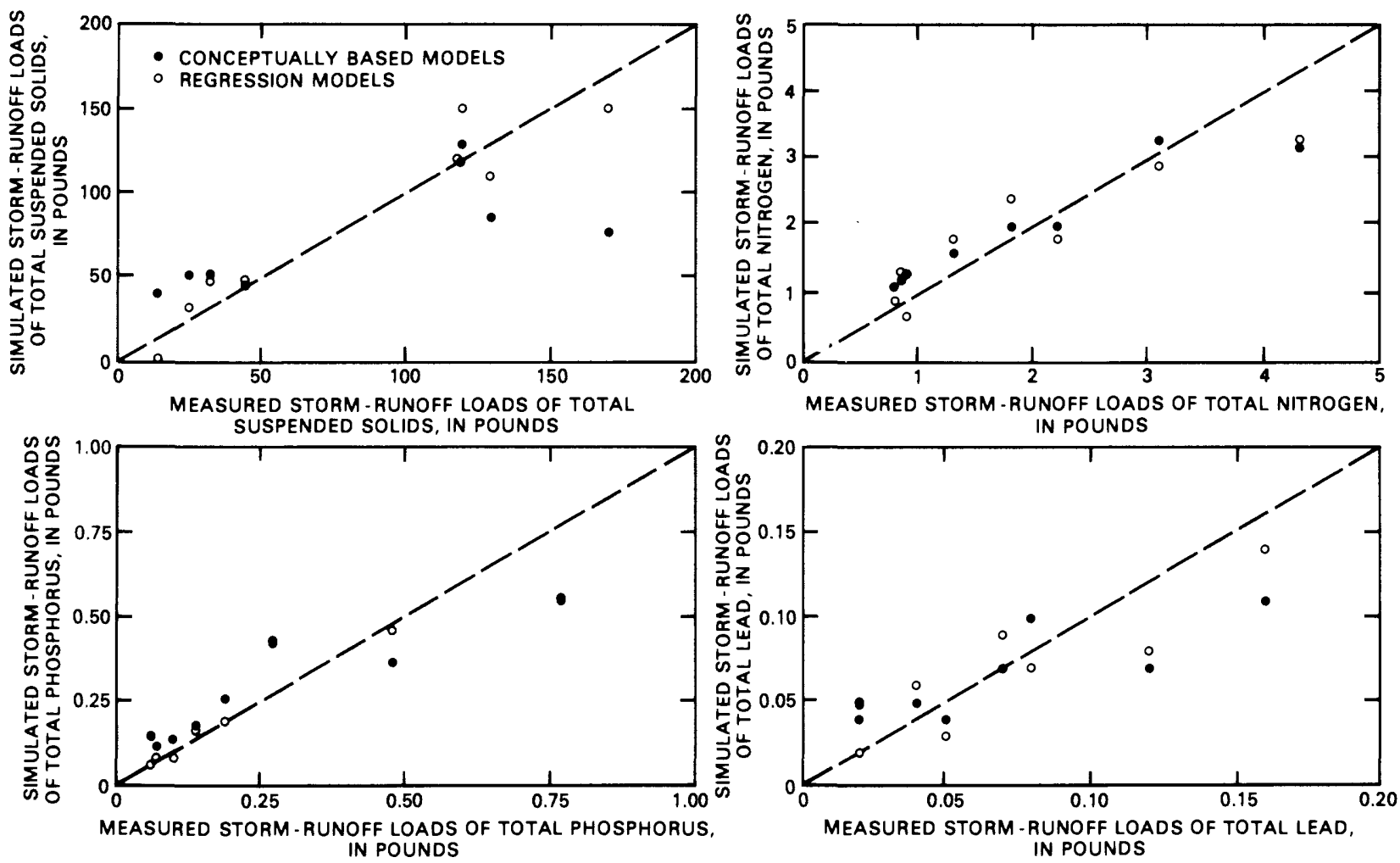

Figure 6.--Simulated versus measured storm-runoff loads for selected constituents for the verification data set for the Cherry Knolls basin.

For both models, the total percentage difference is within 10 percent for all water-quality constituents except total zinc.

The data presented here are the data that were used to calibrate the equation rather than verification data, so the small total percentage difference values are not unexpected. The REG-QUAL method, because of its nature, should result in compensating errors in the storm-runoff loads. Theoretically, coefficients in the regression equation can be adjusted on calibration until simulated values that are too large are balanced by some simulated values that are too small, and the total percentage difference is exactly zero. (Differences from zero primarily are due to rounding.) The $\mathrm{DR}_{3} \mathrm{M}-\mathrm{QUAL}$ also was calibrated to result in a small total percentage difference. However, because this model is conceptually based, the parameter values must make physical sense. In some instances, combinations of parameter values that are required mathematically to make the total percentage difference equal zero do not make physical sense, so the $\mathrm{DR}_{3} \mathrm{M}-\mathrm{II}$ calibration results may not equal zero.

Analysis of the RMSE and MAD values for both types of models indicate that there is very little difference in the abilities of the models to simulate individual storm-runoff loads, except for total manganese, where REG-QUAL produced more accurate estimates than did $\mathrm{DR}_{3} \mathrm{M}$-QUAL. However, in general, both models were able to be calibrated fairly accurately for individual storm-runoff loads. 


\section{Villa Italia Basin}

The Villa Italia basin is unusual in that 91 percent of the basin is effective impervious area, consisting of buildings and parking lots. Pervious-area runoff contribution virtually is nonexistent. The $\mathrm{DR}_{3} \mathrm{M}-\mathrm{II}$ and REG were calibrated using data from 9 storms and verified using data from 12 storms. A comparison of the simulated storm-runoff volumes and peak flows simulated by the two models are presented in tables 12 and 13 . Comparisons for the verification data set also are plotted in figure 7 .

$\mathrm{DR}_{3} \mathrm{M}-\mathrm{II}$ and REG produced comparable values of total percentage differences, RMSE, and MAD for storm-runoff volume. The differences between the results of the two types of models is well within the error of the measured data. However, REG greatly overestimated the three largest peak flows in the verification data set, whereas $D_{3} M-I I$ simulated the three largest peak flows within the accuracy of the measured data. The Villa Italia basin has a stormsewer network that limits the peak flow to about 80 cubic feet per second. No storms producing flows of this magnitude were included in the calibration data set of the earlier $\mathrm{DR}_{3} \mathrm{M}-\mathrm{II}$ study, and, therefore, they were not included in the calibration of REG either. REG was not able to accurately simulate peak flow in response to intense rainfall that would cause a flow of more than 80 cubic feet per second, but accurate simulation was possible using $\mathrm{DR}_{3} \mathrm{M}-\mathrm{II}$. $D_{3} \mathrm{M}-\mathrm{II}$, with the physical description of the drainage features of the basin, was able to account for the limited capacity of the storm-sewer network. More careful division of available data into calibration and verification data sets may be able to produce more accurate results for basins with complex drainage networks than those obtained in this analysis. Of course, it is not desirable to extrapolate with any model so far beyond the range of calibration data. What is important here (or probably in any complex basin) is that given the same limited calibration data, the conceptually based model was far more effective at extrapolation than the regression model. This feature would make the conceptually based models more useful in some applications.

Water-quality constituent data from six storms were available for calibration, but $\mathrm{DR}_{3} \mathrm{M}-\mathrm{QUAL}$ was difficult to calibrate for the Villa Italia basin. This difficulty was due to the difficulty in determining the storm-runoff loads and physical factors not accounted for in this application of the model. Storm-runoff loads could not be accurately determined because of variations in base flow during many of the storms. Because storm-runoff load is defined as the total-runoff load minus the base-flow load (if base flow is present during the storm runoff), inaccurate estimation of base-flow loads could result in inaccurately calculated storm-runoff loads. The storms for which base flow was present are tabulated in Lindner-Lunsford and Ellis, (1984, table 6), or in Gibbs and Doerfer (1982). Physical factors affecting storm-runoff loads that were not accounted for in the modeling include vehicular traffic during and between storms, quantity of water, water-quality constituents transported into the basin by various means, time since the parking lots were swept, and the efficiency of each sweeping of the parking lots.

Seven storms were used for the verification data set for $D_{3} M-Q U A L$ and REG-QUAL. A comparison of the measured and simulated values of $\mathrm{DR}_{3} \mathrm{M}-\mathrm{QUAL}$ and REG-QUAL are presented in tables 14 and 15, and data for selected constituents in the verification data set are plotted in figure 8 . 
Table 12.--Comparison of conceptually based and regression flow-model calibration results for the Villa Italia basin

[Storm-runoff volume is in inches; peak flow is in cubic feet per second]

\begin{tabular}{|c|c|c|c|c|c|c|}
\hline \multirow{3}{*}{ Storm date } & \multicolumn{3}{|c|}{ Storm-runoff volume } & \multicolumn{3}{|c|}{ Peak flow } \\
\hline & \multirow[t]{2}{*}{ Measured } & \multicolumn{2}{|c|}{ Simulated } & \multirow[t]{2}{*}{ Measured } & \multicolumn{2}{|c|}{ Simulated } \\
\hline & & $\overline{\mathrm{DR}_{3} \mathrm{M}-\mathrm{II}}$ & REG & & $\mathrm{DR}_{3} \mathrm{M}-\mathrm{II}$ & REG \\
\hline \multicolumn{7}{|l|}{1980} \\
\hline July $1-2-\cdots$ & 0.37 & 0.37 & 0.37 & 21 & 19 & 24 \\
\hline July $30 \cdots$ & .04 & .03 & .04 & 4.8 & 3.5 & 6.0 \\
\hline August $7-1$ & .05 & .04 & .05 & 11 & 8.8 & 16 \\
\hline August $10-1$ & .03 & .02 & .02 & 3.4 & 2.0 & 2.5 \\
\hline August 25- & .30 & .28 & .29 & 23 & 22 & 28 \\
\hline September 8-1-n & .03 & .02 & .03 & 4.5 & 3.2 & 5.6 \\
\hline September $10^{1}$ & .05 & .06 & .06 & 2.2 & 3.4 & 3.5 \\
\hline September $10^{2}$ & .05 & .07 & .06 & 19 & 21 & 20 \\
\hline September 20 & .14 & .13 & .15 & 33 & 24 & 26 \\
\hline 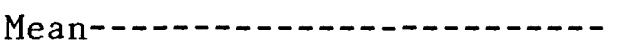 & .12 & .11 & .12 & 13.5 & 11.9 & 13.4 \\
\hline Total percentage difference-- & & -3.8 & 0 & & -12 & -0.8 \\
\hline \multicolumn{7}{|l|}{ Root-mean-square error (RMSE) } \\
\hline Untransformed, in percent-- & & 0.11 & 7.6 & & 20 & 24 \\
\hline Log-transformed, in $\log$ units & & .111 & .067 & & .133 & .114 \\
\hline $\begin{array}{l}\text { Natural-log-transformed, in } \\
\text { natural log units (LN) }\end{array}$ & & .257 & .155 & & .307 & .263 \\
\hline \multicolumn{7}{|l|}{ Mean absolute deviation (MAD) } \\
\hline $\begin{array}{l}\text { Untransformed, in same units } \\
\text { as measured data. }\end{array}$ & & 0.0111 & 0.00654 & & 2.378 & 2.154 \\
\hline Log-transformed, in log units & & .0957 & .0434 & & .1162 & .0855 \\
\hline
\end{tabular}

${ }^{1}$ First storm.

${ }^{2}$ Second storm. 
Table 13.--Comparison of conceptually based and regression flow-model verification results for the Villa Italia basin

[Storm-runoff volume is in inches; peak flow is in cubic feet per second]

\begin{tabular}{|c|c|c|c|c|c|c|}
\hline \multirow{3}{*}{ Storm date } & \multicolumn{3}{|c|}{ Storm-runoff volume } & \multicolumn{3}{|c|}{ Peak flow } \\
\hline & \multirow[t]{2}{*}{ Measured } & \multicolumn{2}{|c|}{ Simulated } & \multirow[t]{2}{*}{ Measured } & \multicolumn{2}{|c|}{ Simulated } \\
\hline & & $\overline{\mathrm{DR}_{3} \mathrm{M}-\mathrm{II}}$ & REG & & $\mathrm{DR}_{3} \mathrm{M}-\mathrm{II}$ & REG \\
\hline \multicolumn{7}{|l|}{1981} \\
\hline March 20-1. & 0.08 & 0.08 & 0.10 & 10 & 6.8 & 8.0 \\
\hline April 19- & .28 & .27 & .28 & 33 & 19 & 25 \\
\hline April 20- & .49 & .49 & .47 & 77 & 67 & 110 \\
\hline May $3^{1} \ldots \ldots$ & .14 & .13 & .14 & 14 & 6.9 & 9.4 \\
\hline May $3^{2}-\ldots$ & .08 & .08 & .06 & 22 & 16 & 13 \\
\hline May $3^{3}-\ldots$ & .04 & .06 & .05 & 4.6 & 4.1 & 3.0 \\
\hline May $12-13$ & .26 & .29 & .29 & 13 & 11 & 13 \\
\hline May 16 & .25 & .24 & .25 & 8.8 & 11 & 12 \\
\hline May $17-18$ & .70 & .70 & .68 & 14 & 15 & 29 \\
\hline June $3^{4} \ldots \ldots$ & .91 & .89 & .84 & 77 & 91 & 250 \\
\hline July 12 & .11 & .11 & .12 & 12 & 11 & 13 \\
\hline July $26^{4}$ & .81 & .79 & .79 & 66 & 74 & 130 \\
\hline Mean-- & .35 & .34 & .34 & 29 & 28 & 51 \\
\hline Total percentage difference-- & & -0.48 & -1.9 & & -5.3 & 75 \\
\hline \multicolumn{7}{|l|}{ Root-mean-square error (RMSE) } \\
\hline Untransformed, in percent-- & & 3.8 & 5.1 & & 26 & 120 \\
\hline Log-transformed, in $\log$ units & & .050 & .058 & & .13 & .20 \\
\hline $\begin{array}{l}\text { Natural-log transformed, in } \\
\text { natural log units (LN). }\end{array}$ & & .11 & .13 & & .30 & .46 \\
\hline \multicolumn{7}{|l|}{ Mean absolute deviation (MAD) } \\
\hline $\begin{array}{l}\text { Untransformed, in same units } \\
\text { as measured data. }\end{array}$ & & 0.010 & 0.018 & & 5.7 & 26 \\
\hline Log-transformed, in $\log$ units & & .026 & .040 & & .11 & .19 \\
\hline
\end{tabular}

${ }^{1}$ First storm.

${ }^{2}$ Second storm.

${ }^{3}$ Third storm.

4Measured storm-runoff volume adjusted for flow that bypassed gage. 
Table 14.--Comparison of conceptually based and regression

[Measured and simulated

\begin{tabular}{|c|c|c|c|c|c|c|c|c|c|}
\hline \multirow{3}{*}{ Storm date } & \multicolumn{3}{|c|}{ Chemical oxygen demand } & \multicolumn{3}{|c|}{ Total suspended solids } & \multicolumn{3}{|c|}{ Total nitrogen as $\mathrm{N}$} \\
\hline & \multirow[b]{2}{*}{ Measured } & \multicolumn{2}{|c|}{ Simulated } & \multirow[b]{2}{*}{ Measured } & \multicolumn{2}{|c|}{ Simulated } & \multirow[b]{2}{*}{ Measured } & \multicolumn{2}{|c|}{ Simulated } \\
\hline & & $\begin{array}{l}\mathrm{DR}_{3} \mathrm{M}^{-} \\
\mathrm{QUAL}\end{array}$ & $\begin{array}{l}\text { REG- } \\
\text { QUAL }\end{array}$ & & $\begin{array}{l}\mathrm{DR}_{3} \mathrm{ML}^{-} \\
\mathrm{QUAL}\end{array}$ & $\begin{array}{l}\text { REG- } \\
\text { QUAL }\end{array}$ & & $\begin{array}{l}\mathrm{DR}_{3} \mathrm{M}^{-} \\
\text {QUAL }\end{array}$ & $\begin{array}{l}\text { REG- } \\
\text { QUAL }\end{array}$ \\
\hline \multicolumn{10}{|l|}{$\underline{1980}$} \\
\hline July 1-2-1-n & -730 & 930 & 510 & 570 & 1,000 & 530 & 20 & 27 & 15 \\
\hline August 25 & -440 & 570 & 470 & 260 & 550 & 290 & 11 & 12 & 13 \\
\hline September $8-9-\ldots$ & -520 & 770 & 630 & 190 & 800 & 210 & 16 & 23 & 20 \\
\hline \multicolumn{10}{|l|}{$\underline{1981}$} \\
\hline March 20-1- & $-\quad 170$ & 110 & 380 & 260 & 95 & 230 & 7.2 & 2.1 & 8.4 \\
\hline May $27-\ldots$ & -560 & 490 & 410 & 890 & 470 & 920 & 10 & 12 & 10 \\
\hline July $26-\ldots$ & -710 & 730 & 720 & 1,300 & 850 & 1,300 & 25 & 29 & 24 \\
\hline Mean---n & -520 & 600 & 520 & 580 & 630 & 580 & 15 & 18 & 15 \\
\hline $\begin{array}{l}\text { Total percentage } \\
\text { difference-- }\end{array}$ & & 15 & 0 & & 8.5 & 0 & & 18 & 0 \\
\hline \multicolumn{10}{|l|}{$\frac{\text { Root-mean-square }}{\text { error (RMSE) }}$} \\
\hline $\begin{array}{l}\text { Untransformed, in } \\
\text { percent. }\end{array}$ & & 27 & 21 & & 60 & 6 & & 24 & 21 \\
\hline $\begin{array}{l}\text { Log-transformed, } \\
\text { in log units. }\end{array}$ & & .109 & .089 & & .396 & .045 & & .209 & .081 \\
\hline $\begin{array}{l}\text { Natural-log- } \\
\text { transformed, } \\
\text { in natural } \\
\text { log units (LN). }\end{array}$ & & .251 & .488 & & .911 & .103 & & .482 & .186 \\
\hline \multicolumn{10}{|l|}{$\frac{\text { Mean absolute }}{\text { deviation (MAD) }}$} \\
\hline $\begin{array}{l}\text { Untransformed, in } \\
\text { same units as } \\
\text { measured data. }\end{array}$ & & 122 & 120 & & 394 & 27 & & 4.35 & 2.26 \\
\hline $\begin{array}{l}\text { Log-transformed, } \\
\text { in log units. }\end{array}$ & & .108 & .125 & & .349 & .032 & & .167 & .064 \\
\hline
\end{tabular}


quality-model calibration results for the Villa Italia basin

values are loads, in pounds]

\begin{tabular}{|c|c|c|c|c|c|c|c|c|c|c|c|}
\hline \multicolumn{3}{|c|}{ Total phosphorus as $\mathrm{P}$} & \multicolumn{3}{|c|}{ Total lead } & \multicolumn{3}{|c|}{ Total manganese } & \multicolumn{3}{|c|}{ Total zinc } \\
\hline \multirow{2}{*}{ Measured } & \multicolumn{2}{|c|}{ Simulated } & \multirow[b]{2}{*}{ Measured } & \multicolumn{2}{|c|}{ Simulated } & \multirow[b]{2}{*}{ Measured } & \multicolumn{2}{|c|}{ Simulated } & \multirow[b]{2}{*}{ Measured } & \multicolumn{2}{|c|}{ Simulated } \\
\hline & $\begin{array}{l}\mathrm{DR}_{3} \mathrm{M}- \\
\text { QUAL }\end{array}$ & $\begin{array}{l}\text { REG- } \\
\text { QUAL }\end{array}$ & & $\begin{array}{l}\mathrm{DR}_{3} \mathrm{M}- \\
\text { QUAL }\end{array}$ & $\begin{array}{l}\text { REG- } \\
\text { QUAL }\end{array}$ & & $\begin{array}{l}\mathrm{DR}_{3} \mathrm{M-}- \\
\text { QUAL }\end{array}$ & $\begin{array}{l}\text { REG- } \\
\text { QUAI }\end{array}$ & & $\begin{array}{l}\mathrm{DR}_{3} \mathrm{M-} \\
\text { QUAL }\end{array}$ & $\begin{array}{l}\text { REG- } \\
\text { QUAL }\end{array}$ \\
\hline 1.5 & 3.3 & 1.3 & 0.80 & 1.67 & 0.52 & 1.1 & 0.94 & 0.76 & 1.3 & 2.0 & 0.80 \\
\hline 1.3 & 1.6 & 1.3 & .47 & .56 & .63 & .36 & .76 & .51 & .66 & .88 & .92 \\
\hline 1.3 & 2.3 & 1.4 & .33 & .83 & .40 & .54 & .95 & .73 & .86 & 1.3 & .67 \\
\hline .43 & .62 & .48 & .32 & .22 & .40 & .26 & .28 & .24 & .32 & .33 & .67 \\
\hline 1.1 & 1.5 & 1.0 & .92 & .48 & .72 & .61 & .66 & .60 & .93 & .75 & 1.0 \\
\hline 4.0 & 2.4 & 4.3 & 1.1 & 1.0 & 1.3 & 1.5 & .88 & 1.6 & 2.1 & 1.3 & 2.1 \\
\hline 1.6 & 2.0 & 1.6 & .66 & .79 & .66 & .73 & .74 & .73 & 1.0 & 1.1 & 1.0 \\
\hline & 22 & 0 & & 21 & 0 & & 2 & 0 & & 6 & 0 \\
\hline & 56 & 10 & & 78 & 33 & & 31 & 27 & & 49 & 29 \\
\hline & .175 & .050 & & .288 & .120 & & .160 & .117 & & .169 & .140 \\
\hline & .403 & .115 & & .664 & .277 & & .369 & .269 & & .390 & .321 \\
\hline & 0.882 & 0.132 & & 0.350 & 0.169 & & 0.277 & 0.126 & & 0.392 & 0.243 \\
\hline & .199 & .037 & & .214 & .114 & & .156 & .082 & & .134 & .141 \\
\hline
\end{tabular}


Table 15.--Comparison of conceptually based and regression

[Measured and simulated

\begin{tabular}{|c|c|c|c|c|c|c|c|c|c|}
\hline \multirow{3}{*}{ Storm date } & \multicolumn{3}{|c|}{ Chemical oxygen demand } & \multicolumn{3}{|c|}{ Total suspended solids } & \multicolumn{3}{|c|}{ Total nitrogen as $\mathrm{N}$} \\
\hline & \multirow[b]{2}{*}{ Measured } & \multicolumn{2}{|c|}{ Simulated } & \multirow[b]{2}{*}{ Measured } & \multicolumn{2}{|c|}{ Simulated } & \multirow[b]{2}{*}{ Measured } & \multicolumn{2}{|c|}{ Simulated } \\
\hline & & $\begin{array}{l}\mathrm{DR}_{3} \mathrm{M}- \\
\text { QUAL }\end{array}$ & $\begin{array}{l}\text { REG- } \\
\text { QUAL }\end{array}$ & & $\begin{array}{l}\mathrm{DR}_{3} \mathrm{M-} \\
\text { QUAL }\end{array}$ & $\begin{array}{l}\text { REG- } \\
\text { QUAL }\end{array}$ & & $\begin{array}{l}\mathrm{DR}_{3} \mathrm{M}- \\
\text { QUAL }\end{array}$ & $\begin{array}{l}\text { REG- } \\
\text { QUAL }\end{array}$ \\
\hline \multicolumn{10}{|l|}{1980} \\
\hline $\begin{array}{l}\text { July } \\
\text { July } 30 \\
\text { August } 10 \\
\text { September } 8 \\
\text { September } 10^{1}\end{array}$ & $\begin{array}{l}240 \\
140 \\
470 \\
210 \\
100\end{array}$ & $\begin{array}{l}100 \\
280 \\
270 \\
110 \\
120\end{array}$ & $\begin{array}{l}380 \\
350 \\
340 \\
350 \\
360\end{array}$ & $\begin{array}{r}160 \\
200 \\
200 \\
130 \\
61\end{array}$ & $\begin{array}{l}100 \\
290 \\
280 \\
110 \\
140\end{array}$ & $\begin{array}{r}490 \\
410 \\
190 \\
1,000 \\
650\end{array}$ & $\begin{array}{l}7.1 \\
6.9 \\
4.0 \\
4.4 \\
9.5\end{array}$ & $\begin{array}{l}2.6 \\
6.5 \\
6.8 \\
2.5 \\
6.1\end{array}$ & $\begin{array}{l}8.4 \\
7.0 \\
6.6 \\
6.8 \\
7.4\end{array}$ \\
\hline \multicolumn{10}{|l|}{1981} \\
\hline $\begin{array}{l}\text { May } 3^{2} \ldots \\
\text { May } 16\end{array}$ & $\begin{array}{r}380 \\
790\end{array}$ & $\begin{array}{l}340 \\
330\end{array}$ & $\begin{array}{l}350 \\
450\end{array}$ & $\begin{array}{r}52 \\
600\end{array}$ & $\begin{array}{l}330 \\
320\end{array}$ & $\begin{array}{l}220 \\
530\end{array}$ & $\begin{array}{l}6.7 \\
14\end{array}$ & $\begin{array}{l}8.0 \\
10\end{array}$ & $\begin{array}{l}7.2 \\
12\end{array}$ \\
\hline Mean- & 330 & 220 & 370 & 200 & 220 & 500 & 7.5 & 6.1 & 7.9 \\
\hline $\begin{array}{l}\text { Total percentage } \\
\text { difference- }\end{array}$ & & -33 & 11 & & 12 & 150 & & -19 & 5.3 \\
\hline \multicolumn{10}{|l|}{$\begin{array}{l}\text { Root-mean-square } \\
\text { error (RMSE) }\end{array}$} \\
\hline $\begin{array}{l}\text { Untransformed, in } \\
\text { percent. }\end{array}$ & & 27 & 8.8 & & 51 & 150 & & 32 & 12 \\
\hline $\begin{array}{l}\text { Log-trans formed, } \\
\text { in } \log \text { units. }\end{array}$ & & .21 & .039 & & .24 & .28 & & .23 & .055 \\
\hline $\begin{array}{c}\text { Natural-log- } \\
\text { transformed, } \\
\text { in natural } \\
\text { log units (IN). } \\
\text { Mean absolute } \\
\text { deviation (MAD) }\end{array}$ & & .49 & .090 & & .56 & .64 & & .52 & .13 \\
\hline $\begin{array}{l}\text { Untransformed, in } \\
\text { same units as } \\
\text { measured data. }\end{array}$ & & 160 & 180 & & 130 & 320 & & 2.6 & 1.6 \\
\hline $\begin{array}{l}\text { Log-transformed } \\
\text { in } \log \text { units. }\end{array}$ & & .24 & .26 & & .29 & .49 & & .19 & .099 \\
\hline
\end{tabular}

1 First storm.

${ }^{2}$ Second storm. 
quality-model verification results for the Villa Italia basin

values are loads, in pounds]

\begin{tabular}{|c|c|c|c|c|c|c|c|c|c|c|c|}
\hline \multirow{2}{*}{\multicolumn{3}{|c|}{ Total phosphorus as $\mathrm{P}$}} & \multicolumn{3}{|c|}{ Total lead } & \multicolumn{3}{|c|}{ Total manganese } & \multicolumn{3}{|c|}{ Total zinc } \\
\hline & & & \multirow[b]{2}{*}{ Measured } & \multicolumn{2}{|c|}{ Simulated } & \multirow[b]{2}{*}{ Measured } & \multicolumn{2}{|c|}{ Simulated } & \multirow[b]{2}{*}{ Measured } & \multicolumn{2}{|c|}{ Simulated } \\
\hline Measured & $\begin{array}{l}\mathrm{DR}_{3} \mathrm{M}- \\
\text { QUAL }\end{array}$ & $\begin{array}{l}\text { REG- } \\
\text { QUAL }\end{array}$ & & $\begin{array}{l}\mathrm{DR}_{3} \mathrm{M}- \\
\text { QUAL }\end{array}$ & $\begin{array}{l}\text { REG- } \\
\text { QUAL }\end{array}$ & & $\begin{array}{l}\mathrm{DR}_{3} \mathrm{M}- \\
\mathrm{QUAL}\end{array}$ & $\begin{array}{l}\text { REG- } \\
\text { QUAL }\end{array}$ & & $\begin{array}{l}\mathrm{DR}_{3} \mathrm{M}- \\
\mathrm{QUAL}\end{array}$ & $\begin{array}{l}\text { REG- } \\
\text { QUAL }\end{array}$ \\
\hline 0.35 & 0.38 & 0.48 & 0.25 & 0.12 & 0.40 & 0.21 & 0.15 & 0.37 & 0.32 & 0.21 & 0.67 \\
\hline 1.4 & 1.2 & .30 & .52 & .41 & .40 & .39 & .32 & .24 & 1.1 & .65 & .67 \\
\hline .71 & 1.1 & .16 & .32 & .40 & .26 & .42 & .32 & .14 & .53 & .63 & .54 \\
\hline .36 & .43 & .27 & .15 & .13 & .45 & .17 & .15 & .47 & .28 & .24 & .67 \\
\hline .65 & .43 & .25 & .20 & .13 & .26 & .26 & .19 & .29 & .35 & .24 & .54 \\
\hline .78 & 1.2 & .23 & .17 & .38 & .26 & .23 & .42 & .18 & .32 & .70 & .54 \\
\hline 1.5 & .99 & .81 & 1.2 & .29 & .40 & .84 & .54 & .54 & 1.2 & .58 & .67 \\
\hline .82 & .82 & .36 & .40 & .27 & .34 & .36 & .30 & .32 & .59 & .46 & .61 \\
\hline & -.35 & -57 & & -34 & -15 & & -17 & -12 & & -21 & 4.9 \\
\hline & .37 & .26 & & 36 & 18 & & 27 & 42 & & 35 & 12 \\
\hline & .16 & .25 & & .25 & .10 & & .15 & .24 & & .21 & .051 \\
\hline & .36 & .56 & & .57 & .23 & & .35 & .54 & & .47 & .12 \\
\hline & 0.26 & 0.50 & & 0.22 & 0.22 & & 0.12 & 0.18 & & 0.26 & 0.30 \\
\hline & .13 & .40 & & .25 & .23 & & .14 & .25 & & .20 & .23 \\
\hline
\end{tabular}



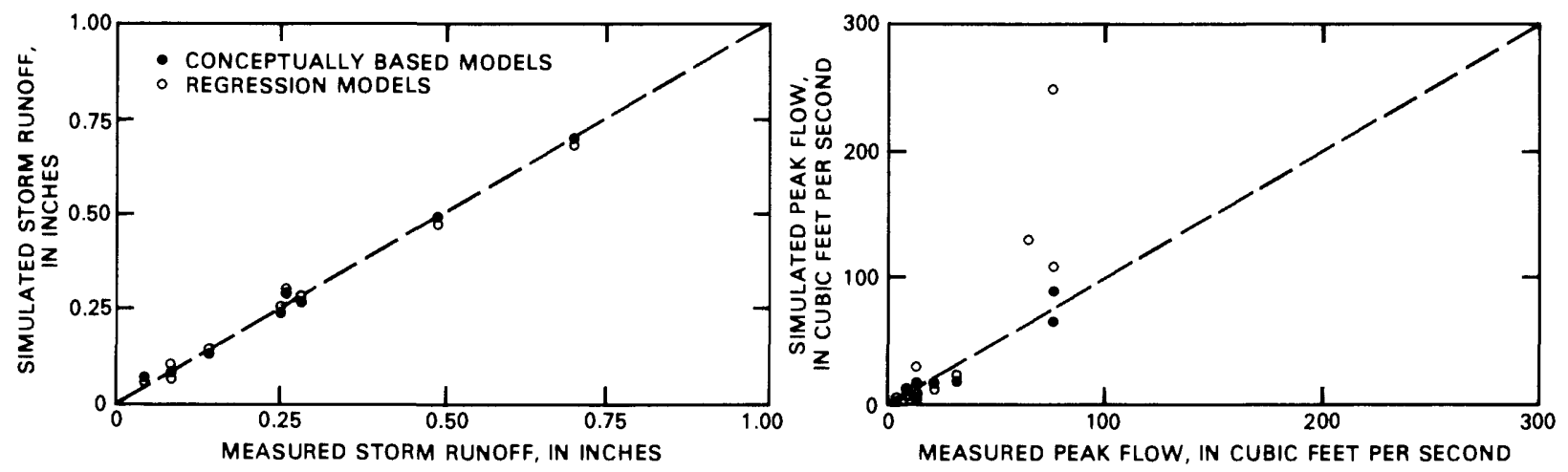

Figure 7.--Simulated versus measured storm-runoff volumes and peak flows for the verification data set for the Villa Italia basin.
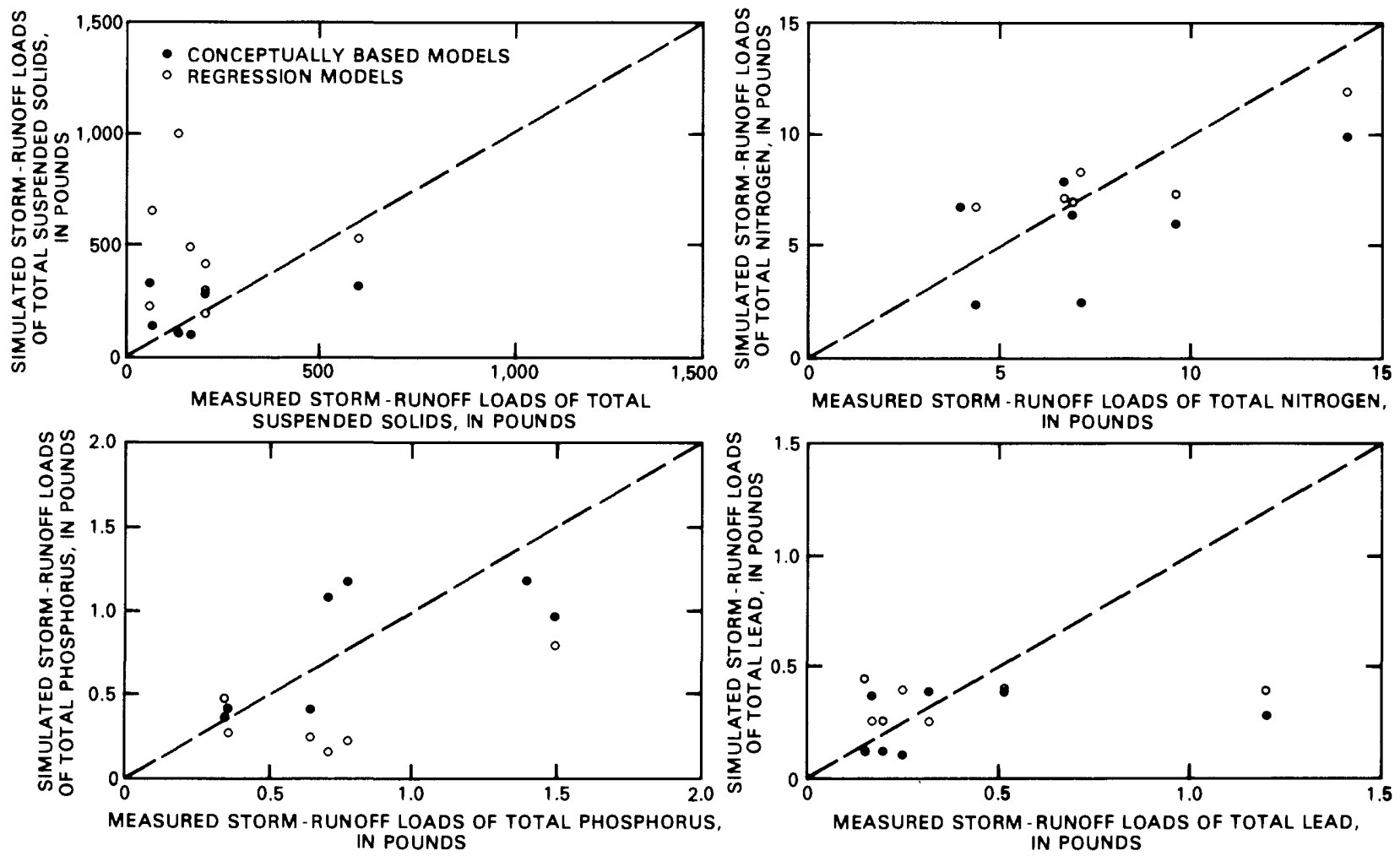

Figure 8.--Simulated versus measured storm-runoff loads for selected constituents for the verification data set for the Villa Italia basin. 
Neither $D_{3} M-Q U A L$ nor REG-QUAL was capable of simulating total or individual storm-runoff loads very accurately. RMSE and MAD values for both types of models are very large when compared to the mean of the measured values; thus, any estimate of storm-runoff loads from individual storms could contain large errors. At best, the models could be used to simulate total stormrunoff loads on a seasonal basis to an acceptable degree of accuracy for planning purposes.

\section{POTENTIAL APPLICATIONS IN URBAN AREAS}

The comparison between conceptually based and regression models in this report is a site-specific comparison, but the concepts are transferable to other urban areas. E1lis and others (1984) have determined that regression models may be regionalized for the Denver metropolitan area. The results of E11is and others (1984) and Driver and Lystrom (1986) indicate that the urbanrunoff process is not unique or site specific, but the urban-runoff process is similar in areas with similar yearly precipitation. Therefore, the conclusions of this study should be valid for other semiarid areas.

Comparison of estimates of storm-runoff quantity and quality from urban areas produced by multievent, conceptually based and single-event multiple linear-regression models for small urban basins in the Denver metropolitan area has indicated a need for careful consideration of the type of stormrunoff model to apply in a given situation. The estimates obtained from the conceptually based models generally are no more accurate than those of the regression models. Choice of which type of model to use then becomes a question of context; the questions that the study addresses need to be examined in terms of the types of predictions needed and whether the greater detail required by the conceptually based models is justified by the necessity of producing vastly more detailed results.

Both the conceptually based and regression models provided accurate estimates of storm-runoff volumes (usually within 0.02 inch). Because, for most storms in semi-arid regions, only the effective impervious areas contributed runoff, even simple calculations could provide estimates of storm-runoff volumes. For small storms, storm-runoff volume can be calculated by:

$$
R O=(R F \cdot E I A)-I R,
$$

where $R O=$ storm-runoff volume, in inches;

$\mathrm{RF}=$ rainfall, in inches;

$\mathrm{EIA}=$ effective impervious area, expressed as a percentage of total basin area; and

$I R=$ depth of impervious retention, in inches,

as shown in Lindner-Lunsford and E1lis (1984, p. 15). Therefore, if the purpose of a study is just to obtain an estimate of storm-runoff volume, it is not necessary to use a complex model. 
Peak flows for most basins also can be simulated reasonably accurately by both conceptually based and regression models. Peak flows from basins that have simple drainage networks can be simulated using a regression model; thus the more time-consuming and data-intensive conceptually based models need not be applied to these basins. Peak flows from basins that contain complex drainage networks, such as the Villa Italia basin in this study, can be more accurately simulated using conceptually based models.

A consistent disadvantage of the regression models when compared to the conceptually based models is that the regression models are incapable of making accurate predictions outside of the range of data in the calibration data set. In this study, the choice of which storms from a given basin were to be included in the calibration data set and which were to be included in the verfication data set was biased toward a division of storms that would better represent the real world--calibrations on limited data, usually small storms, and applications on larger storms. When the conceptually based part of the study was conducted there were no plans to model the same data using a regression model and, hence, there was no incentive to divide the storms in a manner that might aid development of a regression model. Because the regression model is less physically based, it is more important to have a full range in sizes of storms in the calibration data set for this model than it is for the conceptually based model. The fact remains, however, that the conceptually based model was more accurate in prediction of runoff characteristics for storms of a magnitude outside of the range of calibration than the regression model. In particular, peak flows in the verification data sets for the Northglenn and Villa Italia basins were larger than any in the calibration data sets for these two basins. For the Northglenn basin, the largest measurement of peak flow in the calibration data set was 29 cubic feet per second, compared to a peak-flow measurement of 123 cubic feet per second in the verification data set. The largest peak-flow measurement in the calibration data set for the Villa Italia basin was 33 cubic feet per second; the verification data set had measurements from three storms whose peak flows were twice this flow or more.

Multievent models as opposed to single-event models of either the conceptually based or the regression type may not be necessary in the Denver area, except possibly for flood-frequency studies. For all but the largest storms in this study, about 90 percent or more of the total runoff originated from the impervious areas. Therefore, the multievent, conceptually based model was not very sensitive to previous rainfall or soil-moisture conditions. The single-event, multiple linear-regression model also indicated that antecedent conditions were not significant in the simulation of peak flows. Few coefficients are shown in the antecedent dry days and storm-duration columns of table 2. These variables would affect runoff from pervious soil and have virtually no effect on runoff from effective impervious areas. The fact that these variables are not significant may indicate that pervious areas have little effect on rainfall-runoff in semiarid locations such as Denver. Multievent models may not be warranted, and single-event models may be considered as alternatives to multievent models for the simulation of storm-runoff volumes and peak flows for urban basins with over about 25 percent effective impervious area for the more frequent smaller storms in semiarid areas similar to the Denver metropolitan area. 
Neither the multievent, conceptually based nor the single-event, multiple linear-regression models were capable of accurately simulating storm-runoff loads. The representation of accumulation and washoff processes of waterquality constituents on impervious surfaces used in the conceptually based model may be oversimplified. Small-scale, rainfall-simulation studies have verified the concept of nonlinear water-quality constituent accumulation and washoff (Mustard and others, 1985), but other factors appear to dominate in larger basins. Some of these factors include vehicular traffic, wind, and activities of people within the basin. Both vehicular traffic and wind can transport constituents into or out of basins. The direction of origin of the traffic or wind can transport different types of constituents. For example, traffic or wind from an urban area can transport nitrogen, carbon, or lead" (from gasoline) into a basin, whereas traffic or wind from an open field can transport nitrogen and phosphorus compounds from decaying vegetation or soil particles. Vehicular traffic within the basin also can grind larger particles into smaller particles, which then can become adsorption surfaces for constituents, or increase the ability of constituents to dissolve in the runoff. Human activities, such as construction within a basin, obviously can alter the runoff characteristics of the basin by changing pervious areas into impervious areas, but more subtle processes such as household refuse-disposal practices, walking of pets, and disposal of leaves, grass, and oil also can greatly affect the quality of runoff from the basin. These processes are difficult to quantify and usually are not included in conceptually based models.

\section{SUMMARY}

Multievent, conceptually based models and single-event, multiple-linear regression models for predicting urban storm-runoff quantity and quality were compared with data from four small (57 to 167 acres) urban basins in the Denver metropolitan area. The basins represented different land-use types-light commercial, single-family housing, and multifamily housing. Both types of models were calibrated using the same data set for each basin. A comparison was made between storm-runoff volumes, peak flows, and storm-runoff loads of seven water-quality constituents simulated by the models, which used identical verification data sets. The multievent, conceptually based models studied were the U.S. Geological Survey's Distributed Routing Rainfall-Runoff Model--Version II $\left(D_{3} M-I I\right)$, the flow model--and the $D_{3}{ }_{3}-Q U A L$, the quality model. The regression models were developed by multiple linear regression analysis which used both log-transformed and untransformed data.

The regression models produced estimates of storm-runoff volumes that were comparable to those produced by the conceptually based model, but produced less accurate estimates of peak flows for three of the four basins. The peak-flow estimates from the regression models were more accurate than those from the conceptually based model for only the North Avenue basin. The regression model was not capable of producing satisfactory estimates of peak flows for basins that had the more complex drainage networks, such as the Villa Italia basin. The conceptually based model more accurately extrapolated predictions beyond the range of the data used for calibration; this was most apparent in predictions of peak flows for the larger or more intense storms at the Northglenn and Villa Italia basins. 
The multievent conceptually based runoff-quality model, $\mathrm{DR}_{3} \mathrm{M}-\mathrm{QUAL}$, was applied to three of the four basins--North Avenue, Cherry Knolls, and Villa Italia. Water-quality constituents modeled included chemical oxygen demand, total suspended solids, total nitrogen, total phosphorus, total lead, total manganese, and total zinc. DR ${ }_{3} M-Q U A L$ was not noticeably more accurate than REG-QUAL in simulating any particular storm-runoff constituent load nor more accurate for any particular basin.

The results of the conceptually based runoff-quality model probably are not sufficiently accurate to be used to simulate an individual storm-runoff load of any water-quality constituent. The model did not accurately simulate the apparently complex accumulation and washoff of water-quality constituents on impervious surfaces in the Denver metropolitan area. Possible reasons for the failure of the model include: (1) The models do not account for all of the factors that affect water-quality-constituent accumulation and washoff; (2) storm-runoff loads could not be measured accurately and, therefore, accurate data for model calibration are not available; and (3) accumulation and washoff processes are not understood well enough to estimate physically based (as opposed to empirically determined) parameters.

The regression model (REG-QUAL) was applied to the same three small urban basins as $\mathrm{DR}_{3} \mathrm{M}-\mathrm{QUAL}$. REG-QUAL was not applied to the Northglenn basin because the small number of storms in the calibration and verification data sets was insufficient to develop statistically significant regression relations. The regression model, as with the conceptually based model, generally was not capable of simulating storm-runoff loads of the selected water-quality constituents accurately.

Both multievent, conceptually based models, $\mathrm{DR}_{3} \mathrm{M}-\mathrm{II}$ and $\mathrm{DR}_{3} \mathrm{M}-\mathrm{QUAL}$, and single-event regression models (REG and REG-QUAL) produced comparable results for storm-runoff volumes and storm-runoff loads for the small storms and small urban basins used in this study. Neither type of model is capable of simulating storm-runoff loads accurately enough to be useful for the prediction of individual water-quality constituent loads.

Calibration and verification of the conceptually based models is more costly and time consuming than for regression models, and about the same accuracy of prediction is obtainable from each. Regression models are not suitable for studies where detailed output hydrographs are needed, or where the simulations of the models will be required to be extended past the range of the calibration data set. For studies of small urban basins with greater than about 25 percent effective impervious area in semiarid areas such as the Denver metropolitan area, single-event regression models may be a viable alternative to multievent, conceptually based models in the simulation of storm-runoff volumes, peak flows, and storm-runoff loads. 


\section{REFERENCES CITED}

Alley, W.M., and Smith, P.E., 1982a, Distributed routing rainfall-runoff model--Version II: U.S. Geological Survey Open-File Report 82-344, $199 \mathrm{p}$. 1982b, A multievent urban runoff quality model: U.S. Geological Survey Open-File Report 82-764, 175 p.

Driver, N.E., and Lystrom, D.J., 1986, Estimation of urban storm-runoff loads: in Urbonas, Ben, and Roesner, L.A., eds., Engineering Foundation Conference on Urban Runoff Quality, New England College, Henniker, N.H., 1986, Proceedings: New York, American Society of Civil Engineers, p. $122-132$.

Ellis, S.R., Doerfer, J.T.; Mustard, M.H., Blakely, S.R., and Gibbs, J.W., 1984, Analysis of urban storm-runoff data and the effects on the South PLatte River, Denver metropolitan area, Colorado: U.S. Geological Survey Water-Resources Investigations Report 84-4159, $66 \mathrm{p}$.

Ellis, S.R., and Mustard, M.H., 1984, A summary of urban runoff studies in the Denver metropolitan area, Colorado: U.S. Geological Survey WaterResources Investigations Report 84-4072, $31 \mathrm{p}$.

Gibbs, J.W., 1981, Hydrologic data for urban storm runoff from nine sites in the Denver metropolitan area, Colorado: U.S. Geological Survey Open-File Report 81-682, $142 \mathrm{p}$.

Gibbs, J.W. and Doerfer, J.T., 1982, Hydrologic data for urban storm runoff in the Denver metropolitan area, Colorado: U.S. Geological Survey Open-File Report 82-872, $552 \mathrm{p}$.

Hardison, C.H., 1971, Prediction error of regression estimates of streamflow characteristics at ungaged sites, in Geological Survey Research, 1971: U.S. Geological Survey Professional Paper 750-C, p. C228-C236.

Helwig, J.T. , and Council, K.A., 1979, SAS Users Guide: Raleigh, N.C., SAS Institute, Inc., $494 \mathrm{p}$.

Lindner-Lunsford, J.B., and Ellis, S.R., 1984, Calibration and verification of a rainfall-runoff model and a runoff-quality model for several urban basins in the Denver metropolitan area, Colorado: U.S. Geological Survey Water-Resources Investigations Report 83-4286, $52 \mathrm{p}$.

Miller, D.N., 1984, Reducing transformation bias in curve fitting: The American Statistician, v. 38, no. 2, p. 124-126.

Mustard, M.H., Ellis, S.R., and Gibbs, J.W., 1985, Runoff characteristics and washoff loads from rainfall-simulation experiments on a street surface and a native pasture in the Denver metropolitan area, Colorado: U.S. Geologica1 Survey Open-File Report 84-820, 44 p. 